https://helda.helsinki.fi

The role of cormorants, fishing effort and temperature on the catches per unit effort of fisheries in Finnish coastal areas

\title{
Lehikoinen, Aleksi
}

2017-06

Lehikoinen , A , Heikinheimo , O , Lehtonen , H \& Rusanen , P 2017 , ' The role of cormorants, fishing effort and temperature on the catches per unit effort of fisheries in Finnish coastal areas ' , Fisheries Research , vol. 190 , pp. 175-182 . https://doi.org/10.1016/j.fishres.2017.02.008

http://hdl.handle.net/10138/307391

https://doi.org/10.1016/j.fishres.2017.02.008

cc_by_nc_nd

acceptedVersion

Downloaded from Helda, University of Helsinki institutional repository.

This is an electronic reprint of the original article.

This reprint may differ from the original in pagination and typographic detail.

Please cite the original version. 
1 The role of cormorants, fishing effort and temperature on the catches per unit effort of

2 fisheries in Finnish coastal areas

3

4 Aleksi Lehikoinen $^{1 *}$, Outi Heikinheimo ${ }^{2}$, Hannu Lehtonen ${ }^{3}$, Pekka Rusanen ${ }^{4}$

$6{ }^{1}$ The Helsinki Lab of Ornithology, Finnish Museum of Natural History, University of

7 Helsinki, P. O. Box 17, FI-00014 University of Helsinki, Finland.

$8 \quad{ }^{2}$ Natural Resources Institute Finland (Luke), Viikinkaari 4, FI-00791 Helsinki,

9 Finland.

$10{ }^{3}$ University of Helsinki, Department of Environmental Sciences, PO Box 65, FIN-

1100014 Helsinki, Finland.

$12{ }^{4}$ Finnish Environment Institute, Natural Environment Centre, Mechelininkatu 34 a,

13 P.O. Box 140, FI-00251 Helsinki, Finland.

$15 *$ corresponding author, aleksi.lehikoinen@helsinki.fi

17 Abstract

18 Population increase of piscivorous cormorants in Europe and in North America has

19 created a conflict between fisheries and the species. The impact of cormorants on

20 natural fish populations and yields of fishermen is still under debate. We investigated

21 potential connection of the great cormorant Phalacrocorax carbo abundance, fishing

22 effort and water temperature with the economically important perch Perca fluviatilis

23 and pikeperch Sander lucioperca yields, measured as catches per unit of effort

24 (CPUE) in gillnet fishing along the Finnish coastal areas (Baltic Sea) using $50 \mathrm{~km}$

25 International Council for the Exploration of the Sea (ICES) grids. Since cormorants 
26 generally take smaller prey than fishermen, we expected 2-5 years time lag effect of

27 the cormorant numbers on CPUE. Correspondingly, we expected 4-7 years lag effect

28 of temperature on CPUE. Despite the population increase of cormorants, CPUE of

29 perch increased in 10 out of 29 ICES grids during the study period 2005-2014.

30 Pikeperch CPUE increased in five out of 24 grids and decreased in one. There was

31 significant annual variation in CPUE values of perch and pikeperch, but values were

32 not significantly associated with changes in cormorant numbers and temperature

33 either annually or long-term. However, the CPUE values of pikeperch decreased

34 towards the north, which is likely temperature driven as northern colder waters are

35 less suitable for this species than southern waters. There was no clear evidence that

36 either predation by cormorants or fishing effort are associated with long-term trends

37 of perch and pikeperch stocks on a larger scale along the Finnish coast. The

38 increasing CPUE values in several areas indicate that stocks are more abundant than

39 ten years ago despite an increasing cormorant population. Our study approach can be

40 used to monitor potential changes in stocks and impacts of cormorant in the future.

43 Keywords: cormorant, climate change, fisheries, predator-prey interactions 
45

46

47

48

49

50

51

52

1. Introduction

Population sizes of the piscivorous great cormorant Phalacrocorax carbo and doublecrested cormorant Phalacrocorax auritus (hereafter together cormorants) have increased strongly in many European countries (great cormorant) and in North America (double-crested cormorant) creating a conflict between fisheries and the species (Carss, 2004; Fielder, 2010a,b; Rudstam et al., 2004; Van Dam and Asbirk, 1997; Veldcamp, 1996). The impact of cormorants on natural fish populations and fish catches is under ongoing debate. Some studies have suggested that cormorant numbers can limit fish stocks (Fielder, 2008, 2010a; Rudstam et al., 2004; Vetemaa et al., 2010) whereas others have found no effect (Dalton et al., 2009; Diana 2010, Diana et al., 2006; Engström, 2001b; Lehikoinen et al., 2011; Östman et al., 2012). Most of these studies concern local cases, and the potential role of cormorants has rarely been investigated on a larger spatial scale.

The great cormorant population in the Baltic Sea has increased strongly in recent decades. On the northern edge of the Baltic Sea, the species bred for the first time in Finland in 1996 (Lehikoinen, 2006) and in 2014 the population consisted of 20,000 pairs. This has been suggested to particularly affect perch Perca fluviatilis and pikeperch Sander lucioperca populations, which are the two major prey species that have economic importance for fisheries (Lehikoinen, 2005, Mustamäki et al., 2013, Salmi et al., 2015). However, the potential effect of cormorant predation on the catches of the fishermen cannot be distinguished if the effect of environmental variables and fishing itself are not taken into account (Heikinheimo and Lehtonen, 2016; Marzano et al., 2013). 
According to cormorant diet studies in the southwestern coastal waters of

71 Finland, perch is an important food object in all studied areas, making up $21-43 \%$ of the diet by mass. Contrastingly, pikeperch only appears important for cormorants in the inner archipelago, comprising a 10\% share of the diet, as the cormorants mainly take prey species that are abundant in their feeding areas (Salmi et al., 2015). Gillnet fishing is also concentrated in the inner archipelago, increasing especially in the 2000s, as the disturbance by grey seals (Halichoerus grypus) has made fishing almost impossible in the outer parts of the archipelago (Heikinheimo and Lehtonen, 2016; Lehtonen and Suuronen, 2004). Most cormorant colonies are situated in the same areas important for commercial coastal fisheries and thus are partly exploiting the same fish resources. As a consequence, effect on fisheries catches could be expected in those areas. However, in the southwestern archipelago, the mortality caused by cormorants on young pikeperch was not higher than 0.04-0.13 (annual instantaneous mortality), which was much less than other natural mortality, at a maximum third of the total mortality in these age groups (Heikinheimo et al., 2016). The cormorant predation mortality on perch has not been studied. Salmi et al., 2015; Troynikov et al., 2013), which is why there is seldom any direct competition on the same fish individuals. However, if cormorants prey upon substantial amount of fish of the younger age classes, the yields of the fishermen might be affected after a time lag (Salmi et al., 2015). Nevertheless, the mortality

91 effect caused by cormorants may be small if the prey fish stock is dense and the natural mortality from other sources is high (Heikinheimo et al., 2016). Heikinheimo 
94 fisheries catches can be easily overestimated without taking the year class fluctuations and compensatory processes in the fish population into account.

The aim of this study is to investigate how cormorant predation and weather conditions is connected with perch and pikeperch yields, measured as catches per unit of effort in gillnet fishing along the Finnish coastal areas. Climatic conditions, especially temperature, are known to strongly affect the survival of the young-of-theyear of perch and pikeperch (Heikinheimo et al., 2014; Lappalainen et al., 1996, 2000) and this influences the harvests of fishermen after a time lag (Pekcan-Hekim et al., 2011). Our study questions were whether cormorant numbers and water temperature affected the yields of fishermen with a time lag, as a consequence of increased mortality of young fish. We investigated this by examining the change in catch per unit effort (hereafter CPUE) as an index of fish abundance both (i) in the long-term and (ii) annually in a large spatial area. (iii) Third, we investigated, based on population growth rates, how much the cormorant population would still be able to grow in the area. When investigating the potential impact of cormorants on fish stocks, other potential factors such as temperature and fishing effort should be included. Our hypothesis is that cormorant numbers would have a negative effect on fish stocks and therefore we would expect to have decreasing CPUE values in areas with high cormorant densities compared to areas with low cormorant densities. Although our main interest was to investigate the impact of cormorants on fish stocks, it is important to control the potential effect of temperature. Increased temperature improves survival of the young-of-the-year perch and pikeperch and positively affects the yields of fishermen once these age groups have grown to a certain size (PekcanHekim et al., 2011). Last, if fishing effort from the year before is negatively connected with CPUE values, it suggests that harvesting is regulating fish stocks. 
119 Based on our knowledge this topic has not been studied empirically on such a large

120 spatial scale before.

122 2. Methodology

123

124 2.1. Cormorant and fisheries data

125

126 The cormorant population of Finland has been intensively monitored along the whole

127 coastline and each of the colonies have been surveyed from the start of colonization

128 using single visit nest counts during the incubation period in May or early June. Since

129 colonies are easy to detect and the species has received a lot of media attention, we

130 are very confident that all of the colonies have been monitored from the start, i.e.

131 since 1996 (see Lehikoinen, 2006). The most recent monitoring year was 2015 (P.

132 Rusanen, Finnish Environment Institute). Although cormorant numbers have

133 generally increased, there have also been local changes in dynamics and in some areas

134 the population has been declining (Lehikoinen et al., 2011). This enables comparison

135 between areas with increasing, stable or decreasing cormorant numbers.

136 The fisheries data consist of catch and effort statistics of commercial gillnet fisheries

137 (36-60 mm bar length) (Pirkko Söderkultalahti, Natural Resources Institute Finland)

138 that are gathered in $50 \mathrm{~km}$ grids following the marine regional divisions of the

139 International Council for the Exploration of the Sea (ICES statistical rectangles; Fig.

140 1a). These data were used to calculate annual catches $(\mathrm{kg})$ per unit of effort (in

141 number of gillnet days), (CPUE) for perch and pikeperch in each ICES statistical

142 rectangle. The gillnet effort, as the number of fishing days, is calculated separately for

143 each species from the catch observations deviating from zero in the reporting period, 
144 which is one month in the coastal fisheries. The CPUE is the catch $(\mathrm{kg})$ of the given

145 species per gear and per fishing day calculated from observations deviating from zero.

146 CPUE is used as an index of fish abundance (Ricker 1975). This assumption is well

147 valid for e.g. net fishing so long as significant gear saturation did not occur (Hilborn

148 and Walters 1992, p. 175). When a single population is being fished, and when effort

149 is proportional to rate of fishing mortality, it is well established that CPUE is

150 proportional to the mean catchable stock present during the time fishing takes place

151 (Ricker 1975). In commercial fishery, the CPUE typically results from thousands of

152 individual units of fishing effort (Hilborn and Walters 1992), such as gillnet days in

153 this case. The Baltic Marine Environment Protection Commission (Helsinki

154 Commision, HELCOM) is for instance commonly using the CPUE values in their

155 core indicators for evaluating the Good Environmental Status of the Baltic Sea

156 (HELCOM 2015). The CPUE values were calculated by dividing the catch with the

157 effort

158

159

(1) $\mathrm{CPUE}_{\mathrm{j}, \mathrm{t,i}}=$ Catch $_{\mathrm{j}, \mathrm{t}, \mathrm{i}} /$ Effort $_{\mathrm{j}, \mathrm{t}, \mathrm{i}}$

160

161 where Catch and Effort are the catch and gillnet effort of the species $\mathrm{j}$ (perch or

162 pikeperch) in year $\mathrm{t}$ in grid $\mathrm{i}$, respectively. Grids with no gillnet effort targeted on

163 these species were omitted from the analyses. We used unit $\mathrm{kg} / 100$ gillnet days in

164 the analyses. The statistics were available till year 2014, and we used data from the

165 last 10 years (2005-2014) when the cormorant population has been at its highest in

166 the study area. Altogether there are 29 ICES grids along the Finnish coast, but

167 pikeperch is targeted by fishing in only 24 of them because the species is rare in the

168 northern part of the study area and in the outer archipelago (Fig. 1a, Supp. Table 1) 

many grids large parts of the area are not suitable for perch, pikepearch or cormorants

171 due to land area and open deep waters). We calculated the number of breeding

172 cormorant pairs annually in each grid based on the annual locations and sizes of the

173 colonies (P. Rusanen, Finnish Environment Institute). Since cormorants are eating

174 smaller prey than those taken by fisheries (Lehikoinen et al., 2011, Salmi et al., 2015),

175 we used a time lag in the cormorant numbers (mean values of lagged years), when

176 investigating the potential effect of cormorants on catches of fishermen. Depending

177 on growth rate of fish individuals in both perch and pikeperch the fishes preyed upon

178 by cormorants would have mainly reached a suitable size for fishermen after 2 to 5

179 years (the most common ages of preyed pikeperch and perch 2-5 years; Heikinheimo

180 et al., 2016; Salmi et al., 2015). We thus used the mean number of breeding

181 cormorants in each ICES grid cell 2-5 years prior as a proxy for the effect of the

182 cormorant on the CPUE of a given year.

183

184 2.2. Temperature data

186 We calculated the mean annual summer water temperature for each ICES grid cell 187 using the data provided by the Copernicus, Marine Environment Monitoring Service 188 (myocean.eu). More specifically, we used a database called 'Baltic Sea Physics

189 Reanalysis from SMHI (1989-2013)', which provides monthly mean temperatures

190 from a depth of 2 metres throughout the Baltic Sea in $5.5 \mathrm{~km}$ grids. We calculated the 191 mean of all grids that were situated inside each ICES grid. In perch we used the 192 period between June and August, based on the monitoring data of Natural Resources 193 Institute Finland, and for pikeperch we used the period July-August (Heikinheimo et 
al., 2014: Pekcan-Hekim et al., 2011). Since temperature may affect the survival of 0year class fishes (Lappalainen et al., 2000), which would recruit to the harvested population after several years, we used temperature data of 4-7 years before the harvest season. This time lag is based on the fact that most pikeperch and perch

198 (females) become large enough in 5-7 and 4-6 years respectively, to be caught by the

199 gillnets of fishermen (Heikinheimo et al., 2016; Pekcan-Hekim et al., 2011; unpublished perch data of the Natural Resources Institute Finland).

\subsection{Statistical analyses}

2.3.1. Long-term changes

To evaluate how much the cormorant population may yet increase, we investigated the change in annual growth rates of the Finnish cormorant population in relation to the previous year's population size using a linear regression:

where $\mathrm{N}$ is population size in year $\mathrm{t}$ or $\mathrm{t}+1$.

214 We tested how changes in CPUE $_{i, j}$ during the time period 2005-2014 were related to

215 changes in the local cormorant population and water temperature in grid i. First, we

216 calculated the average rate of change in $\mathrm{CPUE}_{\mathrm{i}, \mathrm{j}}$, referred as $\mathrm{bCPUE}_{\mathrm{i}, \mathrm{j}}$, using linear 217 regressions between log-transformed $\mathrm{CPUE}_{\mathrm{i}, \mathrm{j}}$ and years (2005-2014). Second, we 218 examined how bCPUE $\mathrm{E}_{\mathrm{i}, \mathrm{j}}$ might be explained with grid-specific average rate of 
219 changes in cormorant numbers during 2003-2012, the maximum number of breeding

220 cormorants during 2003-2012, and average rate of change in temperature 2000-2009.

221 Here we used a time lag in cormorant numbers (grid specific log-transformed

222 maximum annual number of breeding pairs during years 2003-2012, two year time

223 lag with the CPUE values). Furthermore, we used a grid specific log-transformed

224 maximum value of breeding cormorant pairs as the maximum value of cormorants in

225 the grid. Correspondingly, we investigated the rate of change in temperatures during

226 summer (see species specific periods above) using a five-year time lag for the CPUE

227 values (2000-2009). Temperature data was not log-transformed. Since trend in

228 cormorant numbers and maximum number of cormorants were strongly correlated ( $\mathrm{r}$

$229=0.66$ ), we did not use these two variables in the same model. Our model were thus

(3) $\mathrm{bCPUE}_{\mathrm{i}, \mathrm{j}} \sim \mathrm{bCor}_{\mathrm{i}}+\mathrm{bTemp}_{\mathrm{i}}$

(4) bCPUE $_{\mathrm{i}, \mathrm{j}} \sim$ Cormax $_{\mathrm{i}}+\mathrm{bTemp}_{\mathrm{i}}$

234 where bCPUE is average long-term change in CPUE in species $\mathrm{j}$ in grid $\mathrm{i}, \mathrm{bCor}$ and

235 Cormax are growth rate and log-transformed maximum size of cormorant population

236 in grid $\mathrm{i}$, and bTemp is the rate of change in temperature in grid $\mathrm{i}$. We used the $\mathrm{R}$

237 function $1 \mathrm{~m}$ for the long-term analyses.

239 2.3.2. Annual variation

241 Furthermore, we used linear mixed effect models to explain the annual changes in

242 ICES grid specific log-transformed perch and pikeperch CPUE values (function lme 243 of nlme package in program R). 
Our explanatory variables were: log-transformed catch per unit effort $\left(\mathrm{CPUE}_{\mathrm{t}-1}\right)$,

245 fishing effort year before $\left(\mathrm{Ef}_{\mathrm{t}-1}\right)$, mean temperature (Temp, depending on species 5 to

2467 or 4 to 6 years before, see Temperature data above), number of breeding cormorants

2472 to 5 years before (Cor), latitude coordinate of the grid (Lat), and study year (Year).

248 The equation of the full model was

(5) CPUEi $_{i, t, j} \sim$ CPUE $_{i, t-1, j}+$ Ef $_{i, t-1, j}+$ Temp $_{i, t-1 a g, j}+$ Cor $_{t-l a g, j}+$ Lat $_{j}+$ Year + 1 | grid,

where CPUEi $i_{i, t, j}$ is catch per unit values of species $i$, in year $t$ and from grid $j . \mathrm{Ef}_{\mathrm{i}, \mathrm{t}-1, \mathrm{j}}$ is the fishing effort of the fish species $i$ one year before $(t-1)$. Temp $\mathrm{i}_{\mathrm{i}, \mathrm{t}-\mathrm{lag}, \mathrm{j}}$ is temperature in grid $\mathrm{j}$ based on lag and time requirements of species $\mathrm{i}$. Cor t-lag,j $_{\mathrm{j}}$ is a mean number of breeding cormorants $2-5$ years before in grid $\mathrm{j}$ and Lat $\mathrm{j}$ is the latitude of the grid. Year is study year as a categorical variable and grid was included as a random factor. The base model included only CPUE $_{\mathrm{i}, \mathrm{t}-1, \mathrm{j}}$ and Year as fixed variables and grid as a random factor. In the annual analyses, we used R function lme of the nlme package. We used CPUE of the previous year $\left(\mathrm{CPUE}_{\mathrm{i}, \mathrm{t}-1, \mathrm{j}}\right)$ to account for autoregressive 261 dynamics. Furthermore, the effort year before could reveal the impact of fisheries on fish stocks. Negative relationship between CPUE and effort year before could indicate that increasing fishing effort may have caused decreased fish stocks. The fishing

264 effort and the cormorant numbers were log-transformed $(\ln ($ value +1$))$ before the 265 analyses because of large variation in the magnitude of the cormorant numbers. Since 266 the fishing effort and temperature were strongly negatively correlated with the latitude 267 we transformed temperature into ICES grid specific temperature anomalies (mean 0 268 within each grid), as we were interested in the effect within each grid annually. 
269 Furthermore, there was still strong negative collinearity between cormorant numbers 270 and latitude (-0.46 and -0.50 for perch and pikeperch, respectively, both of which are

271 close to the recommendations given by Booth et al. (1994); $|\mathrm{r}|<0.5)$. We did not

272 standardize cormorant values, since we need the non-standardized values to test if

273 spatial differences in cormorant population size are associated with CPUE. Instead,

274 we avoided using cormorant numbers and latitude in the same model. Otherwise the 275 correlation between variables was lower, $|\mathrm{r}|<0.42$.

276 We tested the connection between fishing effort, temperature, cormorants and 277 latitude with CPUE values separately for perch and pikeperch. We used Akaike

278 information criteria to do the model selection (Burnham \& Anderson, 2002). We did 279 not consider models within 2 AIC units of each other or the top model, but included 280 uninformative parameter(s) (sensu Arnold, 2010).

281 All the analyses were conducted in R version 3.3.1 (R Core Team, 2016).

283 3. Results

285 3.1. Change in cormorant numbers

287 The Finnish cormorant population consisted of c. 23,000 pairs in 2015. The annual 288 population growth rates of cormorant have strongly declined during last 15 years (Fig.

289 2) and the population is mainly concentrated to the western and southern sea areas

290 (Fig. 1b). There are no colonies around inland lakes in Finland. 
294 For perch average long-term change in CPUE were significantly positive in 10 out of

29529 ICES grids during 2005-2014, whereas significantly negative trends were not

296 found in any of grids. Correspondingly, in pikeperch significantly increasing trends

297 were found in five grids out of 24 and a significant decreasing trend was found in one

298 grid (Suppl. Table 2; Fig. 1a). Grid-specific trends in temperature and cormorant

299 numbers or the maximum size of cormorant population were not significantly

300 connected with the average long-term change in CPUE in the corresponding grids

301 either in perch or pikeperch (Table 1; Fig. 3). The significant intercepts in the both

302 perch models and in one out of the two pikeperch models suggested generally average

303 long-term increase in the CPUE values (Table 1).

3.3. Annual variation in CPUE

In perch, none of the models were clearly better than the base model, which included

308 CPUE $_{\mathrm{t}-1}$ and year (AICc difference less than 2; Table 2). Thus, only the base model

309 was considered. CPUE values were positively connected with CPUE values year

310 before suggesting positive autocorrelation (Table 3). Furthermore, CPUE values

311 showed significant annual variation. More specifically, year 2009 had significantly

312 lower and year 2014 significantly higher CPUEs than the starting year (2005), but

313 other years did not significantly differ from that first year (Table 3).

315 In pikeperch, the top ranked model included CPUE year before, latitude and year, and

316 was clearly better than the base model (Table 4). There were three other models

317 within $2 \triangle \mathrm{AICc}$ (Table 4), but all these included the same variables as in the top

318 ranked models and additional variables in these models can be considered as 
uninformative parameter(s) (Arnolds 2010). Thus, we only considered the top ranked model. Based on the coefficients, CPUE values of pikeperch were significantly negatively associated with latitude and significantly positively connected with CPUE

322 values year before suggesting positive autocorrelation (Table 5, Fig. 4).

4. Discussion

326 Our findings show that the average long-term changes in CPUE were mainly non327 significant or positive in perch and pikeperch in ICES grids along the coastal waters 328 of Finland. Furthermore, despite significant annual variation in CPUE values, we did 329 not find any evidence that CPUE values would have been negatively associated with 330 cormorant numbers or fishing effort in the year prior. In addition, there is a clear 331 latitudinal gradient in pikeperch, with CPUE values being larger in the south 332 compared to northern latitudes (see also Pekcan-Hekim et al., 2011). Although our 333 results could not detect any connection between temperature and CPUE values, this 334 gradient is likely climate driven (Lappalainen et al. 1996, 2000). According to our results average long-term changes in CPUE of perch and 336 pikeperch show more increasing than decreasing trends during 2005-2014. As the 337 CPUE is considered an index of fish abundance (Ricker 1975), this suggests that 338 fished stocks of these species have generally increased. Pikeperch CPUE levels have 339 remained relatively stable for decades, except for a temporary peak in 1990s (Pekcan340 Hekim et al., 2011). We are not aware of any temporal change in the efficiency of 341 gears during the study period. In addition, the gillnet material has been the same 342 during the study period. Recent changes in CPUE values could be also climate driven 343 as warmer waters in the northern Baltic Sea are expected to cause an increase in 
344 warm-adapted and freshwater species (Mackenzie et al., 2007) such as perch and

345 pikeperch (Lappalainen et al., 1996). We did not find any evidence that changes in

346 cormorant numbers are linked with change in CPUE, either annually or with long-

347 term average changes. Furthermore, the CPUE trend analyses showed that CPUE

348 values have significantly increased in several ICES grids, but decreased in only one

349 grid in pikeperch. This suggests that despite increasing cormorant populations,

350 fishable stocks of perch and pikeperch are abundant on a larger scale. The result is in

351 concordance with the finding by Heikinheimo et al. (2016) that the mortality of

352 pikeperch caused by cormorants in the Archipelago Sea was low compared to the

353 level of natural mortality from other sources. Also, Heikinheimo and Lehtonen (2016)

354 found no change in the mortality of perch in the same area when the periods before

355 and after the establishment of the cormorant population were compared. If cormorants

356 have an effect on fished populations, it might be more local and cannot be captured

357 with the $50 \mathrm{~km}$ grid resolution. Although our survey grids are relatively large, they are

358 currently the smallest unit where CPUE values can be examined on a larger scale.

359 Furthermore, cormorants are relatively mobile (mean foraging distance $5 \mathrm{~km}$ ) and

360 their feeding area regularly extends up to $25 \mathrm{~km}$ from the breeding colonies (Thaxter

361 et al., 2012). Importantly, our study design covers areas with high cormorant

362 population densities also in European scale (see Bregnballe et al., 2014) as well as

363 areas with no cormorants. This should enhance the potential to detect potential

364 connections between cormorant numbers and changes in fish stocks.

365 Mustamäki et al. (2014) deduced that pikeperch year class strength, based on

366 CPUEs of three-year-old pikeperch in experimental gillnet fishing, was negatively

367 affected by the presence of cormorants in a coastal area of Sweden, but such a trend

368 was not seen in the commercial catches. Although cormorants consume relatively 
369 large number of fishes, they typically take smaller fish than commercial fisheries

370 (Lehikoinen et al., 2011, Salmi et al., 2015). As the mortality of young age groups is

371 generally high, a large part of the cormorant predation may not be additive to other

372 mortality (Hilborn and Walters, 1992; Heikinheimo et al., 2016). Compensatory

373 mechanisms such as density-dependent mortality and growth (Rose et al., 2001;

374 Heikinheimo et al. 2016) counteract the effect of predation mortality on fisheries

375 catches. Despite this, there are local studies which indicate that e.g. perch populations

376 can be less dense near cormorant colonies, however it is not known whether is this

377 due to predation or indirect effects such as changes in water quality and vegetation, or

378 avoidance of areas with higher predation risk (Gagnon et al., 2015).

With perch, one explanation to the missing connection between cormorant abundance and fisheries CPUEs is that cormorants eat both small sized males and

381 females, but it is mainly females that grow large enough to be caught by fishermen

382 (Heikinheimo and Lehtonen, 2016). Therefore, assuming that all perch taken by

383 cormorants would have grown to the sizes caught with gillnets leads to overestimate

384 of potential catch losses (Salmi et al. 2015; Heikinheimo and Lehtonen, 2016).

Not only are cormorants mobile, but some fish are moving too, whereas some

386 are quite sedentary. The range of migration usually depends on the distribution of

387 food resources, the temperature conditions and abundance of neighbouring

388 populations, as well as the morphology of the archipelago (Aro, 1989). For example,

389 the migrations of perch are shorter in areas where the archipelago zone is narrow.

390 When the area of shallow archipelago is extensive, the migrations are longer. About

391 half of the recaptures of tagged perch in Finnish coastal waters are made at a distance

392 of about $20 \mathrm{~km}$ from the point of release (Böhling and Lehtonen, 1984). The dispersal

393 area of tagged pikeperch was also small in areas where the tagging site was 
surrounded by a sparse archipelago. Locations where the dispersal area was large usually had good connections with other archipelagos. In most cases, $75 \%$ of pikeperch recaptures were made within a distance of $10 \mathrm{~km}$ from the tagging point (Lehtonen and Toivonen, 1987). Since the dispersal distances seem to me relatively short, the CPUE values of the grids are less likely driven by mixing of several grids. Lappalainen et al. $(1996,2000)$ have shown that survival of zero-year-old perch and pikeperch is higher in warmer temperatures, which explains the latitudinal pattern. It is possible that our study period was not long enough to catch this climatic effect, as especially in pikeperch CPUE peak years caused by the climatic fluctuation are scarce (Pekcan-Hekim et al., 2011), but temperature is still the main factor

404 explaining the year-class strength in pikeperch (Heikinheimo et al. 2014). In addition, 405 temperature data from the whole grid cell may not necessarily reflect the conditions experienced by young-of-the-year perch and pikeperch as spawning typically occurs

407 in shallow waters (Lehtonen et al., 1996; Snickars et al., 2005; Veneranta et al., 408 2011).

409 We found no clear evidence that fishing effort in the year prior predicts CPUE 410 values. This may be due to the fact that there were no large changes in the effort 411 during the study period. Commercial fishing with gillnets has been intense in the 412 2000s compared to earlier decades (Pekcan-Hekim et al., 2011). Due to the increased 413 disturbance caused by grey seals (Lehtonen and Suuronen, 2004) in many coastal 414 areas in the 2000s, gillnet fishing has largely moved from the outer archipelago nearer 415 to the coast to more sheltered bay areas, where the fishing effort directed to perch and 416 pikeperch has increased. Accordingly, in the outer archipelago the gillnet effort has 417 decreased. Perch and especially pikeperch are relatively rare in the diet of grey seals 418 in the Baltic ( $4 \%$ and $<1 \%$ in the diet according to Lundström et al., 2010, 
419 respectively; in the Finnish study $<10 \%$ together; Kauhala et al., 2010), and thus seal

420 predation is unlikely any important driver of the perch and pikeperch stocks.

421 Our population growth models of cormorants suggest that the cormorant

422 population growth rate has been slowing down in recent years. The Finnish cormorant

423 densities start to be at the same level as in other Baltic countries, where saturation has

424 been reached already earlier (Bregnballe et al., 2014). If the Finnish population

425 approaches its saturation point, it is unlikely that the cormorant population will cause

426 large-scale declines in perch and pikeperch populations. Nevertheless, this issue

427 should be monitored on a regular basis as the carrying capacity could alter due to

428 changes in environment, such as climate. We believe that our study design provides

429 an appropriate tool to (i) monitor the changes in perch and pikeperch stocks targeted

430 by commercial fishery in the Finnish coastal waters and (ii) examine potential large-

431 scale connections between cormorants and catchable fish stocks, and the analysis

432 could be applied to other areas where similar monitoring is occurring. However, there

433 is likely a need to investigate potential impacts of cormorants on a more local scale.

434 Since the Baltic Sea and its fish community has been predicted to change due to

435 various environmental drivers, not least to climate change (Andersson et al., 2015;

436 Mackenzie et al., 2007; Pekcan-Hekim et al., 2011; Vuorinen et al., 2015), it is

437 important to continue monitoring fish stocks as accurately as possible.

439 Acknowledgements

441 We thank the tens of birdwatchers who participated in the data collection of breeding 442 cormorants. A.L. received financial support from the Academy of Finland (project 
275606). Dominique Potvin kindly checked the language. Comments of Antti

444 Lappalainen and two anonymous referees improved the clarity of the manuscript.

\section{References}

Andersson, A., Meier, H. E. M., Ripszam, M., Rowe, O., Wikner, J., Haglund, P., Eilola, K., Legrand, C., Figueroa, D., Paczkowska, J., Lindehoff, E., Tysklind, M., Elmgren, R. 2015. Projected future climate change and Baltic Sea

Arnold, T. W. 2010. Uninformative parameters and model selection using Akaike's Information Criterion. Journal of Wildlife Management 74, 1175-1178. doi: ecosystem management. Ambio 44, S345-S356. doi:10.1007/s13280-015-06548

Böhling, P., Lehtonen, H. 1984. Effect of environmental factors on migrations of 10.1111/j.1937-2817.2010.tb01236.x

Aro, E. 1989. A review of fish migration patterns in the Baltic Sea. Rapport et ProcésVerbaux des Réunions du Conseil International pour 1'Exploration de la Mer 190, 72-96. perch (Perca fluviatilis L.) tagged in the coastal waters of Finland. Finnish Fisheries Research 5, 31-40.

Booth, G., Niccolucci, M., Schuster, E. 1994. Identifying proxy sets in multiple linear regression: an aid to better coefficient interpretation. U.S. Department of David N. Carss \& van Eerden, M.R. (eds.) 2014. Breeding numbers of Great Cormorants Phalacrocorax carbo in the Western Palearctic, 20122013. IUCN- 

http://dce2.au.dk/pub/SR99.pdf

Burnham, K. P., Anderson, D. R. 2002. Model selection and multimodel inference. Springer, New York.

Carss D. (ed.) 2004. Reducing the conflict between Cormorants and fisheries on a pan-European scale -- REDCAFE Final Report. Centre for Ecology \& Hydrology Banchory.

Dalton C. M., Ellis D., Post D. M. 2009. The impact of double-crested cormorant (Phalacrocorax auritus) predation on anadromous alewife (Alosa pseudoharengus) in south-central Connecticut, USA. Can. J. Fish. Aquat. 66, 177-186. doi: 10.1139/f2012-042

Diana J. S., Maruca S., Low B. 2006. Do increasing cormorant populations threaten sportfishes in the Great Lakes? A case study in Lake Huron. J. Great Lakes Res. 32, 306-320. doi: 10.3394/0380-1330(2006)32[306:DICPTS]2.0.CO;2

Diana, J. S. 2010. Should cormorants be controlled to enhance yellow perch in Les Cheneaux Islands? A comment on Fielder (2008). J. Great Lakes Res. 36, 190194. doi: 10.1016/j.jglr.2009.12.012

Engström, H. 2001. Long-term effects of cormorant predation on fish communities and fishery in a freshwater lake. Ecography 24, 127-138. doi: 10.1034/j.16000587.2001.240203.x

Fielder, D. G. 2008. Examination of Factors Contributing to the Decline of the Yellow Perch Population and Fishery in Les Cheneaux Islands, Lake Huron, with Emphasis on the Role of Double-crested Cormorants. J. Great Lakes Res. 34, 506-523. doi: 10.3394/0380-1330(2008)34[506:EOFCTT]2.0.CO;2 
Fielder D. G. 2010a. Response of yellow perch in Les Cheneaux Islands, Lake Huro to declining numbers of double-crested cormorants stemming from control activities. J. Great Lakes Res. 36, 207-214. doi: 10.1016/j.jglr.2009.12.015

Fielder, D. G. 2010b. Response to Diana Commentary. J. Great Lakes Res. 36: 195198. doi: $10.1016 /$ j.jglr.2009.12.011

Gagnon, K., Yli-Rosti, J., Jormalainen, V. 2015. Cormorant-induced shifts in littoral communities. Mar. Ecol. Prog. Ser. 541, 15-30. doi: 10.3354/meps11548

Heikinheimo, O., Lehtonen, H. 2016. Comment to article by Salmi, J. A. et al., 2015: Perch (Perca fluviatilis) and pikeperch (Sander lucioperca) in the diet of the great cormorant (Phalacrocorax carbo) and effects on catches in the Archipelago Sea, Southwest coast of Finland. Fish. Res. 179, 354-357. doi: 10.1016/j.fishres.2016.01.020

Heikinheimo, O., Rusanen, P., Korhonen, K. 2016. Estimating the mortality caused by great cormorant predation on fish stocks: pikeperch in the Archipelago Sea, northern Baltic Sea, as an example. Can. J. Fish. Aquat. Sci. 73, 84-93. doi: 10.1139/cjfas-2015-0033

Heikinheimo, O., Pekcan-Hekim, Z., Raitaniemi, J. 2014. Spawning stock recruitment relationship in pikeperch, Sander lucioperca, in the Baltic Sea, with temperature as environmental effect. Fish, Res. 155, 1-9. doi: 10.1016/j.fishres.2014.02.015

HELCOM 2015. Abundance of coastal fish key functional groups. HELCOM core indicator report. Online. 27 Jan 2017, http://www.helcom.fi/baltic-seatrends/indicators/abundance-of-coastal-fish-key-functional-groups/.

Hilborn, R., Walters, C. J., 1992. Quantitative fisheries stock assessment. Choice, dynamics and uncertainty. Chapman and Hall, London.

Kauhala, K., Kunnasranta, M., Valtonen, M. 2011. Diet of grey seals in Finland in 

English summary).

521 Lappalainen, J., Lehtonen, H., Böhling, P., Erm, V., 1996. Covariation in yearclass strength of perch, Perca fluviatilis L. and pikeperch Stizostedion lucioperca (L.). Ann. Zool. Fenn. 33, 421-426.

Lappalainen, J., Erm, V., Kjellman, J., Lehtonen, H., 2000. Size-dependent winter mortality of age 0 pikeperch (Stizostedion lucioperca) in Pärnu Bay, the Baltic Sea. Can. J. Fish. Aquat. Sci. 57, 451-458. doi: 10.1139/cjfas-57-2-451

Lehikoinen A. 2005. Prey-switching and Diet of the Great Cormorants During the Breeding Season in the Gulf of Finland. Waterbirds 28, 511-515.

Lehikoinen A. 2006. Cormorants in the Finnish archipelago. Ornis Fenn. 83: 34-46.

Lehikoinen, A., Heikinheimo, O., Lappalainen, A. 2011. Temporal changes in the diet of great cormorant on the southern coast of Finland and comparison to available fish data. Boreal Env. Res. 16(suppl. B), 61-70.

Lehtonen, H., Hansson, S., Winkler, H. 1996. Biology and exploitation of pikeperch, Stizostedion lucioperca (L.), in the Baltic Sea area. Ann. Zool. Fenn. 33, 525535.

Lehtonen, H., Toivonen, J. 1987. Migration of pike-perch, Stizostedion lucioperca (L.), in different coastal waters in the Baltic Sea. Finnish Fish. Res. 7, 24-30. the diet composition of marine mammals: grey seals (Halichoerus grypus) in the Baltic Sea. ICES J. Mar. Sci. 67, 1230-1239. doi: 10.1093/icesjms/fsq022 
Mackenzie, B. R., Gislason, H., Möllmann, C., Köster, F. W. 2007. Impact of $21^{\text {st }}$ century climate change on the Baltic Sea fish community and fisheries. Global Change Biol. 13, 1348-1367. doi: 10.1111/j.1365-2486.2007.01369.x

Marzano, M., Carss, D.N., Cheyne, I. 2013. Managing European cormorantfisheries conflicts: problems, practicalities and policy. Fish. Manag. Ecol. 20, 401-413. doi:10.1111/fme.12025.

Mustamäki, N., Bergström, U., Ådjers, K., Sevastik, A., Mattila, J. 2013. Pikeperch (Sander lucioperca (L.)) in decline: High mortality of three populations in the Northern Baltic Sea. Ambio 43, 325-336. doi: 10.1007/s13280-013-0429-z

Östman, Ö., Bergenius, M., Boström, M. K., Lunneryd, S.-G. 2012. Do cormorant colonies affect local fish communities in the Baltic Sea? Can. J. Fish. Aquat. Sci. 69, 1047-1055. 10.1139/f2012-042

Pekcan-Hekim, Z., Urho, L., Auvinen, H., Heikinheimo, O., Lappalainen, J., Raitaniemi, J., Söderkultalahti, P. 2011. Climate warming and pikeperch yearclass catches in the Baltic Sea. Ambio 40, 447-456. doi: 10.1007/s13280-0110143-7

R Core Team 2016. R: A language and environment for statistical computing. The $R$ Foundation for Statistical Computing, Vienna, Austria, https://www.Rproject.org.

Ricker, E.E. 1975. Computation and interpretation of biological statistics of fish populations. Bull. Fish. Res. Bd. Can. 191. 382 pp.

Rose, K.A., Cowan Jr J.H., Winemiller, K.O., Myers, R.A., Hilborn, R., 2001. Compensatory density dependence in fish populations: importance, controversy, understanding and prognosis. Fish and Fisheries 2, 293-327. 
Rudstam L. G., Van De Valk A. J., Adams C. M., Coleman J. T. H., Forney J. L., Richmond M. E. 2004. Cormorant predation and the population dynamics of walleye and yellow perch in Oneida Lake. Ecol. Appl. 14, 149-163. doi: $10.1890 / 03-5010$

Salmi, J. A., Auvinen, H., Raitaniemi, J., Kurkilahti, M., Lilja, J., Maikola, R. 2015. Perch (Perca fluviatilis) and pikeperch (Sander lucioperca) in the diet of the great cormorant (Phalacrocorax carbo) and effects on catches in the Archipelago Sea, Southwest coast of Finland. Fish. Res. 164, 26-34.

Snickars, M., Sandström, A., Ljunggren, L., Johansson, G. \& Mattila, J. 2005. Perca fluviatilis L. spawning site selectivity in shallow areas of the Baltic Sea. J. Fish. Biol. 67 (Suppl. B), 291-292.

Thaxter, C. B., Lascelles, B., Sugar, K., Cook, A. S. C. P., Roos, S., Bolton, M., Langston, R. H. W., Burton, N. H. K. 2012. Seabird foraging ranges as a preliminary tool for identifying candidate Marine Protected Areas. Biol. Conserv. 156, 53-61. doi: 10.1016/j.biocon.2011.12.009

Troynikov, V., Whitten, A., Gorfine, H., Pūtys, Ž., Jakubavičiūtè, E., Ložys, L., Dainys, J. 2013. Cormorant catch concerns for fishers: Estimating the sizeselectivity of a piscivorous bird. PLoS ONE 8(11): e77518. doi: 10.1371/journal.pone.0077518

Van Dam C., Asbirk S. (eds.) 1997. Cormorants and human interests. Proceedings of the Workshop towards an International Conservation and Management Plan for the Great Cormorant (Phalacrocorax carbo), 3 and 4 October 1996, Lelystad, The Netherlands. Wageningen. 
591 Veldkamp R. 1996. Report: Cormorant Phalacrocorax carbo in Europe, a first step towards a European management plan. Report Bureau Veldkamp XI/226/96, Steenwijk.

594 Veneranta, L., Urho, L., Lappalainen, A., Kallasvuo, M., 2011. Turbidity characterizes the reproduction areas of pikeperch (Sander lucioperca (L.)) in the northern Baltic Sea. Estuar. Coast. Shelf Sci. 95 (1), 199-206. doi: 10.1016/j.ecss.2011.08.032. Hubel K., Hannesson R., Saat T. 2010. Changes in fish stocks in an Estonian estuary: overfishing by cormorants? ICES J. Mar. Sci. 67, 1972-1979. doi:

601 10.1093/icesjms/fsq113

602 Vuorinen, I., Hänninen, J., Rajasilta, M., Laine, P., Eklund, J., Montesino-Pouzols, F., 603 Corona, F., Junker, K., Meier, H. E. M., Dippner, J. W. 2015. Scenario 604 simulations of future salinity and ecological consequences in the Baltic Sea and 605 adjacent North Sea areas - implications for environmental monitoring. Ecol. $606 \quad$ Indic. 50, 196-205. doi: 10.1016/j.ecolind.2014.10.019

607

608 609 610 611 
611 Table 1. Coefficients of variables (model 3: trends in temperature and log-

612 transformed cormorants numbers, model 4: trends in temperature and log-transformed

613 maximum cormorant numbers) explaining the log-transformed long-term change in

614 CPUE values in perch and pikeperch. Significant test-values are bolded.

\begin{tabular}{|c|c|c|c|c|c|c|}
\hline & Perch & & & Pikeperch & & \\
\hline Model 3 & $\mathrm{~B} \pm \mathrm{SE}$ & $\mathrm{t}$ & $\mathrm{P}$ & $\mathrm{B} \pm \mathrm{SE}$ & $\mathrm{t}$ & $\mathrm{P}$ \\
\hline Intercept & $0.042 \pm 0.016$ & 2.56 & 0.017 & $0.049 \pm 0.033$ & 1.47 & 0.157 \\
\hline Temperature & $0.040 \pm 0.308$ & 0.13 & 0.898 & $-0.549 \pm 0.624$ & -0.88 & 0.388 \\
\hline Cormorant trend & $-0.037 \pm 0.045$ & -0.83 & 0.415 & $-0.012 \pm 0.061$ & -0.30 & 0.771 \\
\hline \multicolumn{7}{|l|}{ Model 4} \\
\hline Variable & $\mathrm{B} \pm \mathrm{SE}$ & $\mathrm{t}$ & $\mathrm{P}$ & $\mathrm{B} \pm \mathrm{SE}$ & $\mathrm{t}$ & $\mathrm{P}$ \\
\hline Intercept & $0.052 \pm 0.018$ & 2.83 & 0.009 & $\mathbf{0 . 0 7 8} \pm \mathbf{0 . 0 3 7}$ & 2.11 & 0.047 \\
\hline Temperature & $0.071 \pm 0.302$ & 0.24 & 0.814 & $-0.530 \pm 0.597$ & -0.89 & 0.385 \\
\hline Cormorant max & $-0.005 \pm 0.003$ & -1.38 & 0.180 & $-0.007 \pm 0.005$ & -1.42 & 0.170 \\
\hline
\end{tabular}

615

616

617

618 
619 Table 2. Number of parameters (K), AIC differences corrected for a small sample size

620 ( $\triangle \mathrm{AICc}$ ), and AIC weights of models explaining the annual log-transformed CPUE

621 values of perch in ICES grids on the Finnish coast. CPUE $\mathrm{t}_{\mathrm{t}-1}=\mathrm{CPUE}$ of the last year,

$622 \mathrm{Cor}=$ number of cormorants, $\mathrm{Ef}_{\mathrm{t}-1}=$ catch effort year before, Lat $=$ latitude and Temp

$623=$ temperature. See more detailed in the text.

\begin{tabular}{|c|c|c|c|}
\hline Model & $\mathrm{K}$ & $\triangle \mathrm{AICc}$ & $w$ \\
\hline $\mathrm{CPUE}_{\mathrm{t}-1}+\mathrm{Year}$ & 13 & 0.00 & 0.22 \\
\hline $\mathrm{CPUE}_{\mathrm{t}-1}+\mathrm{Lat}+$ Year & 14 & 0.16 & 0.21 \\
\hline $\mathrm{CPUE}_{\mathrm{t}-1}+\mathrm{Cor}+$ Year & 14 & 1.30 & 0.12 \\
\hline $\mathrm{CPUE}_{\mathrm{t}-1}+$ Temp + Year & 14 & 2.08 & 0.08 \\
\hline $\mathrm{CPUE}_{\mathrm{t}-1}+\mathrm{Ef}_{\mathrm{t}-1}+$ Year & 14 & 2.10 & 0.08 \\
\hline $\mathrm{CPUE}_{\mathrm{t}-1}+\mathrm{Lat}+\mathrm{Temp}+$ Year & 15 & 2.27 & 0.07 \\
\hline $\mathrm{CPUE}_{\mathrm{t}-1}+\mathrm{Ef}_{\mathrm{t}-1}+\mathrm{Lat}+$ Year & 15 & 2.27 & 0.07 \\
\hline $\mathrm{CPUE}_{\mathrm{t}-1}+$ Temp + Cor + Year & 15 & 3.40 & 0.04 \\
\hline $\mathrm{CPUE}_{\mathrm{t}-1}+\mathrm{Ef}_{\mathrm{t}-1}+$ Cor + Year & 15 & 3.44 & 0.04 \\
\hline $\mathrm{CPUE}_{\mathrm{t}-1}+\mathrm{Ef}_{\mathrm{t}-1}+\mathrm{Temp}+$ Year & 15 & 4.19 & 0.03 \\
\hline $\mathrm{CPUE}_{\mathrm{t}-1}+\mathrm{Ef}_{\mathrm{t}-1}+\mathrm{Lat}+\mathrm{Temp}+$ Year & 16 & 4.39 & 0.03 \\
\hline $\mathrm{CPUE}_{\mathrm{t}-1}+\mathrm{Ef}_{\mathrm{t}-1}+$ Temp + Cor + Year & 16 & 5.55 & 0.01 \\
\hline
\end{tabular}

624

625

626

627

628 
629 Table 3. Coefficients of variables after model averaging explaining the annual

630 variation in log-transformed CPUE of perch in ICES grids on the Finnish coast.

631 Coefficients that significantly differ from zero are bolded. CPUE $\mathrm{t}_{\mathrm{t}-1}$ is log-transformed 632 CPUE year before.

\begin{tabular}{lrrrr}
\hline Variable & $\mathrm{B} \pm \mathrm{SE}$ & $\mathrm{Df}$ & t-value & P-value \\
\hline Intercept) & $\mathbf{2 . 0 1} \pm \mathbf{0 . 1 8}$ & 1,251 & 10.90 & $<0.001$ \\
CPUE $_{\mathrm{t}-1}$ & $\mathbf{0 . 2 4} \pm \mathbf{0 . 0 6}$ & 1,251 & 4.15 & $<0.001$ \\
Year 2006 & $0.02 \pm 0.10$ & 1,251 & 0.18 & 0.858 \\
Year 2007 & $0.04 \pm 0.10$ & 1,251 & 0.45 & 0.655 \\
Year 2008 & $0.05 \pm 0.10$ & 1,251 & 0.56 & 0.577 \\
Year 2009 & $\mathbf{- 0 . 2 3} \pm \mathbf{0 . 1 0}$ & 1,251 & -2.38 & 0.018 \\
Year 2010 & $0.01 \pm 0.09$ & 1,251 & 0.09 & 0.926 \\
Year 2011 & $0.13 \pm 0.10$ & 1,251 & 1.38 & 0.169 \\
Year 2012 & $0.19 \pm 0.10$ & 1,251 & 1.97 & 0.051 \\
Year 2013 & $0.15 \pm 0.10$ & 1,251 & 1.48 & 0.141 \\
Year 2014 & $\mathbf{0 . 2 7} \pm \mathbf{0 . 1 0}$ & 1,251 & 2.72 & 0.007 \\
\hline
\end{tabular}

633

634 
635 Table 4. Number of parameters (K), AIC differences corrected for a small sample size

636 ( $\triangle \mathrm{AICc})$, and AIC weights $(w)$ of models explaining the annual log-transformed

637 CPUE values of pikeperch in ICES grids on the Finnish coast. Cor $=$ number of

638 cormorants, Eft-1 = gillnet effort year before, Lat $=$ latitude and Temp $=$ temperature.

639 See more detailed in the text.

\begin{tabular}{lrrr}
\hline Model & $\mathrm{K}$ & $\Delta \mathrm{AICc}$ & $w$ \\
\hline $\mathrm{CPUE}_{\mathrm{t}-1}+\mathrm{Lat}+$ Year & 14 & 0.00 & 0.31 \\
$\mathrm{CPUE}_{\mathrm{t}-1}+\mathrm{Lat}+$ Temp + Year & 15 & 0.00 & 0.31 \\
$\mathrm{CPUE}_{\mathrm{t}-1}+\mathrm{Ef}_{\mathrm{t}-1}+\mathrm{Lat}+$ Year & 15 & 0.96 & 0.19 \\
$\mathrm{CPUE}_{\mathrm{t}-1}+\mathrm{Ef}_{\mathrm{t}-1}+\mathrm{Lat}+$ Temp + Year & 16 & 0.99 & 0.19 \\
$\mathrm{CPUE}_{\mathrm{t}-1}+$ Temp + Year & 14 & 23.29 & 0.00 \\
$\mathrm{CPUE}_{\mathrm{t}-1}+$ Year & 13 & 23.32 & 0.00 \\
$\mathrm{CPUE}_{\mathrm{t}-1}+\mathrm{Ef}_{\mathrm{t}-1}+$ Year & 14 & 23.55 & 0.00 \\
$\mathrm{CPUE}_{\mathrm{t}-1}+\mathrm{Ef}_{\mathrm{t}-1}+$ Temp + Year & 15 & 23.59 & 0.00 \\
$\mathrm{CPUE}_{\mathrm{t}-1}+\mathrm{Cor}^{+}$Year & 14 & 25.17 & 0.00 \\
$\mathrm{CPUE}_{\mathrm{t}-1}+\mathrm{Temp}^{+}$Cor + Year & 15 & 25.26 & 0.00 \\
$\mathrm{CPUE}_{\mathrm{t}-1}+\mathrm{Ef}_{\mathrm{t}-1}+$ Cor + Year & 15 & 25.30 & 0.00 \\
$\mathrm{CPUE}_{\mathrm{t}-1}+\mathrm{Ef}_{\mathrm{t}-1}+$ Temp + Cor + Year & 16 & 25.46 & 0.00 \\
\hline
\end{tabular}

640

641 
641 Table 5. Coefficients and their standard errors of variables from the top ranked model 642 explaining the annual variation in log-transformed CPUE of pikeperch in ICES grids 643 on the Finnish coast. CPUE $\mathrm{t}_{\mathrm{t}-1}$ is the CPUE year before, Latitude is the latitude of the 644 grid cell and different years are compared to the starting year 2005. CPUE $\mathrm{E}_{\mathrm{t}-1}$ is $\log$ 645 transformed CPUE year before.

\begin{tabular}{lrrrr}
\hline Variable & $\mathrm{B} \pm \mathrm{SE}$ & $\mathrm{Df}$ & t-value & P-value \\
\hline (Intercept) & $\mathbf{2 8 . 2 0} \pm \mathbf{4 . 7 3}$ & 1,226 & 5.97 & $<0.001$ \\
CPUE $_{\mathrm{t}-1}$ & $\mathbf{0 . 1 9} \pm \mathbf{0 . 0 6}$ & 1,226 & 3.21 & 0.002 \\
Latitude & $\mathbf{- 0 . 4 3} \pm \mathbf{0 . 0 8}$ & 1,27 & -5.71 & $<0.001$ \\
Year 2006 & $0.05 \pm 0.14$ & 1,227 & 0.35 & 0.723 \\
Year 2007 & $-0.09 \pm 0.14$ & 1,227 & -0.61 & 0.545 \\
Year 2008 & $-0.11 \pm 0.14$ & 1,227 & -0.77 & 0.439 \\
Year 2009 & $-0.14 \pm 0.14$ & 1,227 & -1.00 & 0.319 \\
Year 2010 & $-0.05 \pm 0.15$ & 1,227 & -0.37 & 0.715 \\
Year 2011 & $0.04 \pm 0.14$ & 1,227 & 0.26 & 0.796 \\
Year 2012 & $-0.08 \pm 0.15$ & 1,227 & -0.57 & 0.572 \\
Year 2013 & $0.11 \pm 0.15$ & 1,227 & 0.76 & 0.450 \\
Year 2014 & $0.22 \pm 0.14$ & 1,227 & 1.53 & 0.128
\end{tabular}

646

647

648

649 
649

650 


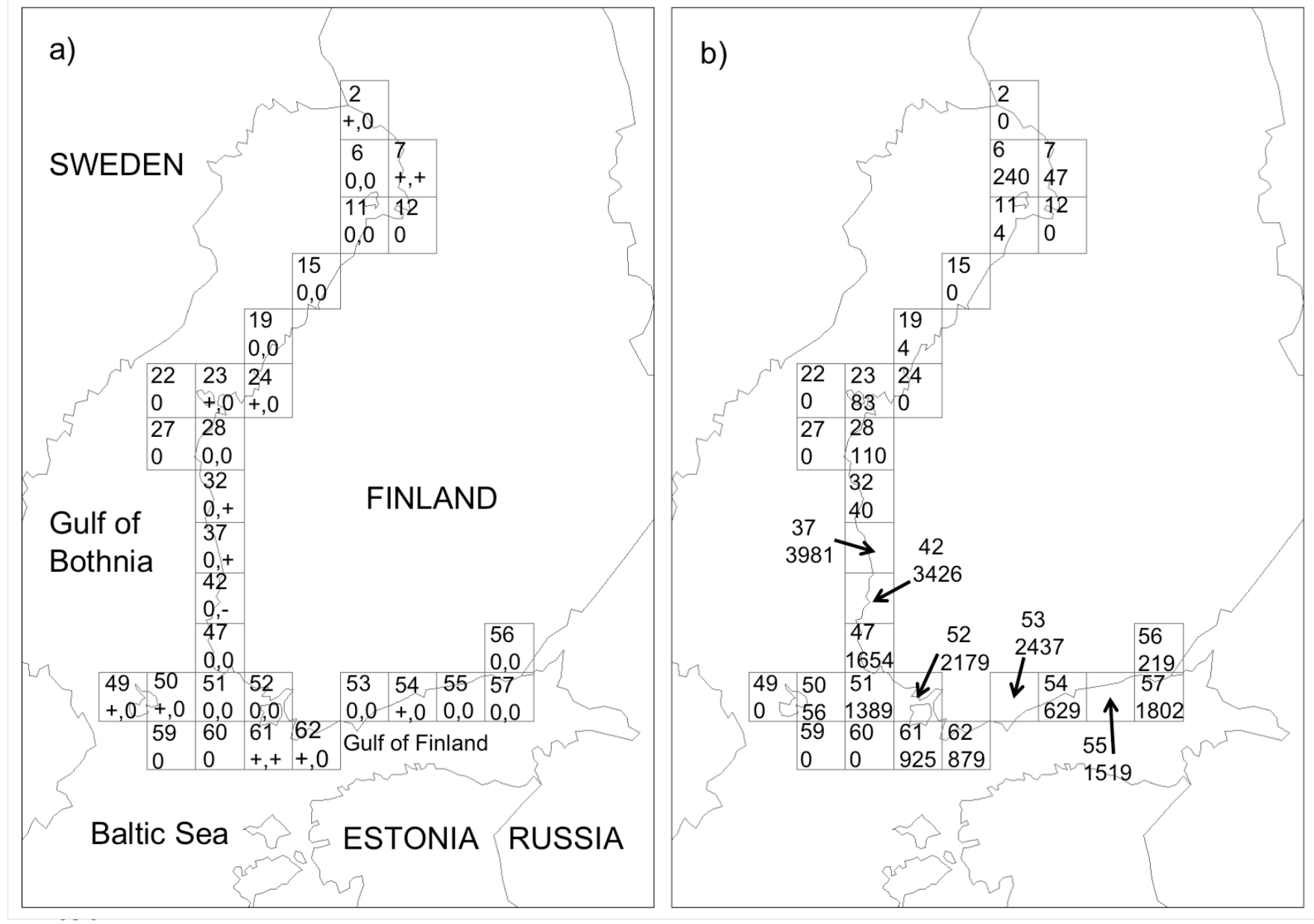

651 Fig. 1. Study grids along the coastal areas of Finland showing (a) significant changes

652 in CPUE values in perch and pikeperch in 2005-2014 and (b) the maximum number

653 of breeding cormorant pairs in Finland in the northern Baltic Sea inside ICES $50 \mathrm{~km}$

654 grids in 2003-2012 (Table 5). In both panels the upper value is the number of the grid

655 cell, in panel (a) the trends $(+=$ positive, $-=$ negative, $0=$ no significant trend $)$ of

656 perch (left) and pikeperch (right) CPUE are shown below. 


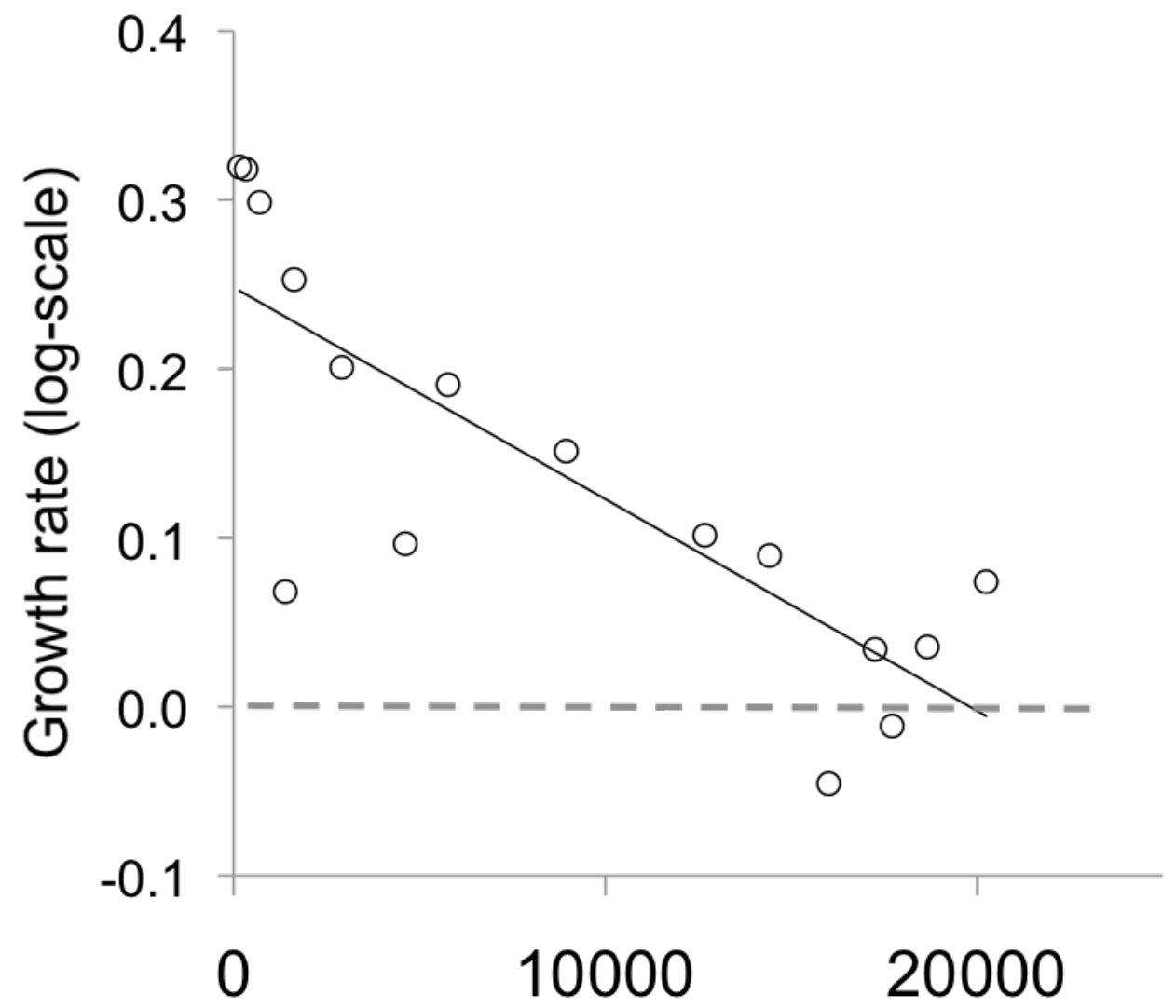

658 Fig. 2. Population growth rate of the Finnish cormorant population $\left(\log \left(\mathrm{N}_{t+1} / \mathrm{N}_{t}\right)\right)$ in 659 relation to population size the year before (year t) during 2000-2015. The linear 660 regression line shows the significant negative correlation between variables $(b=-$ $6610.000013 \pm 0.000002, \mathrm{t}=27.6, \mathrm{P}<0.001)$. 

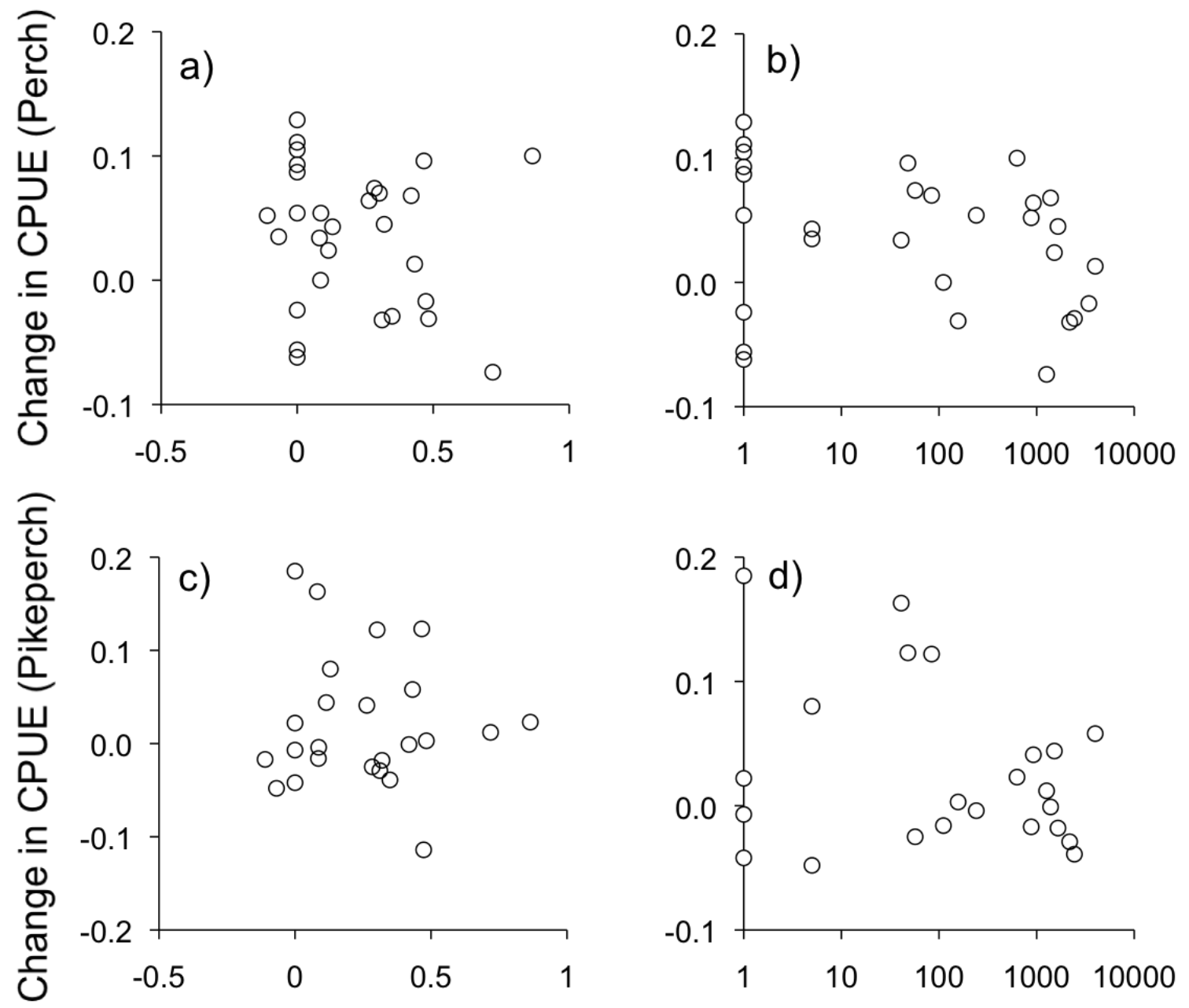

664 Change in Cormorant numbers

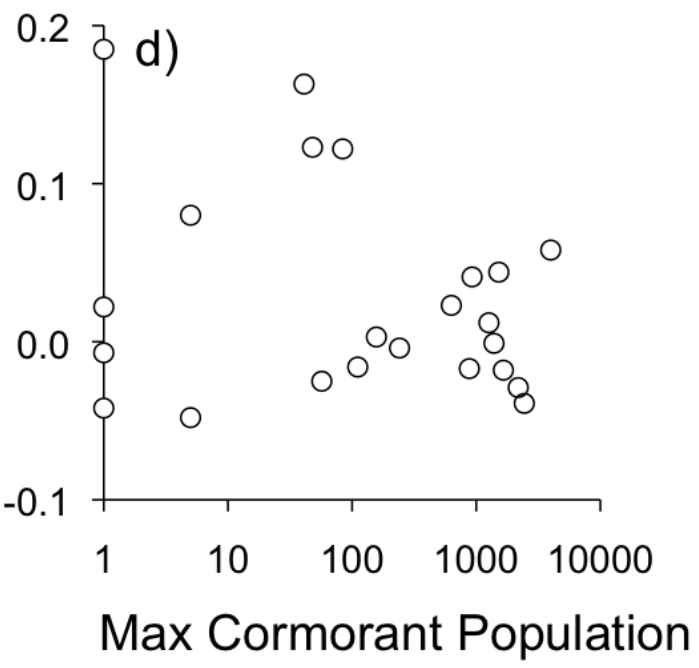

665 Fig. 3. Annual average change of log-transformed CPUE values (unit kg / 100 gillnet 666 days) in (a-b) perch and (c-d) pikeperch during 2005-2014 in relation to (a and c)

667 population growth rates of log-transformed cormorant numbers and (b and d)

668 maximum population size of cormorants (in log-scale) during 2003-2012 in Finnish 669 ICES grids. 


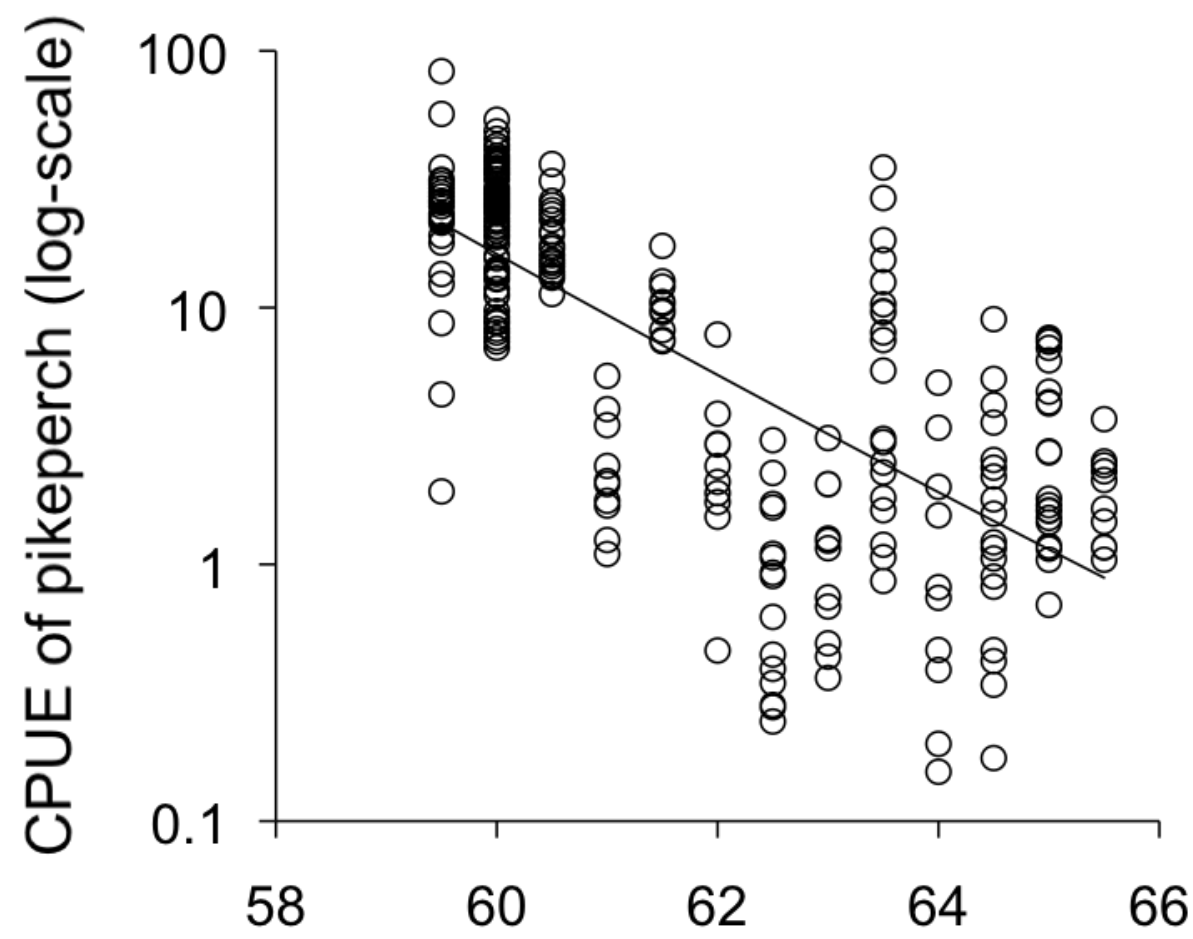

673 Fig. 4. Annual CPUE values (kg / 100 gillnet days) of pikeperch in relation to latitude 674 on Finnish coasts during 2005-2014.

675

676

677 
678 Supplementary table 1 . The data of the analyses including annual grid-specific CPUE

679 values of perch(CPUE ${ }_{\text {Perch }}$ and $\left.\mathrm{CPUE}_{\text {Perch-1 }}\right)$ and pikeperch $\left(\mathrm{CPUE}_{\text {Pikep }}\right.$ and $\mathrm{CPUE}_{\text {Pikep- }}$

680 1 $), \log$-transformed fishing effort of perch $\left(E f_{\text {Perch-1 }}\right)$ and pikeperch $\left(E f_{\text {Pikep-1 }}\right)$ year

681 before, water temperature for perch $\left(\mathrm{T}_{\text {Perch }}\right)$ and pikeperch $\left(\mathrm{T}_{\text {Pikep }}\right), \log$-transformed

682 abundance of cormorants and the latitude (Lat) of the ICES grids (Grid).

\begin{tabular}{|c|c|c|c|c|c|c|c|c|c|c|c|}
\hline Year & CPUE $_{\text {Perch }}$ & CPUE $_{\text {Perch-1 }}$ & CPUE $_{\text {Pikep }}$ & CPUE $_{\text {Pikep-1 }}$ & Ef $f_{\text {Perch-1 }}$ & $\mathrm{Ef}_{\text {Pikep-1 }}$ & $\mathrm{T}_{\text {Perch }}$ & $\mathrm{T}_{\text {Pikep }}$ & Cor & Lat & Grid \\
\hline 2005 & 4.376 & 5.719 & 2.517 & 5.870 & 11.055 & 8.673 & 0.799 & 1.060 & 0.000 & 65.5 & 2 \\
\hline 2006 & 3.776 & 4.376 & 1.648 & 2.517 & 11.079 & 8.818 & 0.459 & 0.820 & 0.000 & 65.5 & 2 \\
\hline 2007 & 6.279 & 3.776 & 1.043 & 1.648 & 11.253 & 8.166 & 0.311 & 0.140 & 0.000 & 65.5 & 2 \\
\hline 2008 & 6.667 & 6.279 & 2.303 & 1.043 & 10.681 & 8.571 & 0.661 & 0.680 & 0.000 & 65.5 & 2 \\
\hline 2009 & 9.282 & 6.667 & 1.162 & 2.303 & 10.299 & 7.946 & 0.501 & 0.730 & 0.000 & 65.5 & 2 \\
\hline 2010 & 7.212 & 9.282 & 2.432 & 1.162 & 10.508 & 8.977 & 0.291 & 0.650 & 0.000 & 65.5 & 2 \\
\hline 2011 & 9.909 & 7.212 & 2.131 & 2.432 & 10.467 & 9.266 & 0.261 & 0.510 & 0.000 & 65.5 & 2 \\
\hline 2012 & 10.154 & 9.909 & 1.169 & 2.131 & 10.584 & 8.167 & 0.351 & 0.460 & 0.000 & 65.5 & 2 \\
\hline 2013 & 8.698 & 10.154 & 1.468 & 1.169 & 10.089 & 8.033 & 0.489 & 0.520 & 0.000 & 65.5 & 2 \\
\hline 2014 & 12.043 & 8.698 & 3.677 & 1.468 & 10.534 & 9.205 & 0.629 & 0.740 & 0.000 & 65.5 & 2 \\
\hline 2005 & 11.016 & 8.776 & 2.727 & 3.571 & 10.748 & 6.043 & 0.799 & 1.041 & 3.590 & 65 & 6 \\
\hline 2006 & 14.956 & 11.016 & 1.042 & 2.727 & 10.582 & 6.089 & 0.429 & 0.671 & 4.107 & 65 & 6 \\
\hline 2007 & 19.721 & 14.956 & 1.151 & 1.042 & 10.587 & 8.302 & 0.321 & 0.249 & 4.410 & 65 & 6 \\
\hline 2008 & 15.704 & 19.721 & 1.701 & 1.151 & 10.547 & 8.102 & 0.731 & 0.769 & 4.677 & 65 & 6 \\
\hline 2009 & 14.619 & 15.704 & 0.696 & 1.701 & 10.724 & 8.793 & 0.511 & 0.689 & 4.984 & 65 & 6 \\
\hline 2010 & 11.298 & 14.619 & 1.179 & 0.696 & 10.156 & 9.079 & 0.241 & 0.509 & 5.127 & 65 & 6 \\
\hline 2011 & 14.633 & 11.298 & 1.517 & 1.179 & 10.441 & 8.430 & 0.271 & 0.479 & 5.302 & 65 & 6 \\
\hline 2012 & 15.181 & 14.633 & 1.803 & 1.517 & 10.610 & 7.623 & 0.391 & 0.489 & 5.361 & 65 & 6 \\
\hline 2013 & 23.337 & 15.181 & 1.458 & 1.803 & 10.939 & 8.803 & 0.469 & 0.531 & 5.281 & 65 & 6 \\
\hline 2014 & 25.480 & 23.337 & 1.614 & 1.458 & 10.647 & 9.219 & 0.769 & 0.941 & 5.162 & 65 & 6 \\
\hline 2005 & 5.868 & 7.677 & 2.756 & 7.328 & 11.134 & 9.735 & 0.749 & 1.120 & 0.000 & 65 & 7 \\
\hline 2006 & 9.115 & 5.868 & 4.706 & 2.756 & 11.193 & 10.328 & 0.339 & 0.740 & 0.000 & 65 & 7 \\
\hline 2007 & 9.280 & 9.115 & 1.626 & 4.706 & 10.971 & 10.035 & 0.251 & 0.110 & 0.000 & 65 & 7 \\
\hline 2008 & 15.557 & 9.280 & 4.229 & 1.626 & 11.083 & 10.005 & 0.541 & 0.610 & 0.000 & 65 & 7 \\
\hline 2009 & 9.417 & 15.557 & 4.288 & 4.229 & 11.103 & 10.013 & 0.341 & 0.600 & 0.000 & 65 & 7 \\
\hline 2010 & 13.234 & 9.417 & 7.361 & 4.288 & 11.278 & 10.108 & 0.241 & 0.610 & 0.000 & 65 & 7 \\
\hline 2011 & 16.603 & 13.234 & 7.546 & 7.361 & 11.178 & 9.920 & 0.391 & 0.600 & 1.386 & 65 & 7 \\
\hline 2012 & 17.483 & 16.603 & 6.970 & 7.546 & 11.077 & 9.445 & 0.521 & 0.630 & 1.792 & 65 & 7 \\
\hline 2013 & 15.109 & 17.483 & 7.628 & 6.970 & 11.127 & 10.291 & 0.399 & 0.440 & 2.546 & 65 & 7 \\
\hline 2014 & 15.282 & 15.109 & 6.232 & 7.628 & 11.276 & 10.442 & 0.799 & 0.860 & 3.199 & 65 & 7 \\
\hline 2005 & 14.667 & 14.692 & 0.340 & 0.545 & 10.759 & 9.273 & 0.815 & 1.551 & 0.000 & 64.5 & 11 \\
\hline
\end{tabular}




\begin{tabular}{|c|c|c|c|c|c|c|c|c|c|c|}
\hline 2006 & 16.390 & 14.667 & 0.176 & 0.340 & 10.674 & 8.083 & 0.385 & 1.091 & 0.000 & 64.5 \\
\hline 2007 & 18.813 & 16.390 & 1.576 & 0.176 & 11.228 & 7.952 & 0.275 & 0.171 & 0.000 & 64.5 \\
\hline 2008 & 8.508 & 18.813 & 0.818 & 1.576 & 10.729 & 8.140 & 0.685 & 0.399 & 0.000 & 64.5 \\
\hline 2009 & 8.794 & 8.508 & 1.219 & 0.818 & 10.954 & 9.175 & 0.465 & 0.339 & 0.000 & 64.5 \\
\hline 2010 & 9.479 & 8.794 & 0.420 & 1.219 & 10.900 & 9.187 & 0.205 & 0.169 & 0.000 & 64.5 \\
\hline 2011 & 18.951 & 9.479 & 1.158 & 0.420 & 11.004 & 9.424 & 0.355 & 0.219 & 0.405 & 64.5 \\
\hline 2012 & 22.188 & 18.951 & 0.463 & 1.158 & 11.033 & 9.103 & 0.465 & 0.239 & 0.811 & 64.5 \\
\hline 2013 & 21.411 & 22.188 & 1.054 & 0.463 & 11.217 & 9.678 & 0.415 & 0.821 & 1.179 & 64.5 \\
\hline 2014 & 17.998 & 21.411 & 0.897 & 1.054 & 11.195 & 9.658 & 0.835 & 1.331 & 1.179 & 64.5 \\
\hline 2005 & 39.353 & 8.751 & - & - & 7.072 & - & 0.759 & - & 0.000 & 64.5 \\
\hline 2006 & 45.392 & 39.353 & - & - & 7.735 & - & 0.339 & - & 0.000 & 64.5 \\
\hline 2007 & 24.552 & 45.392 & 2.198 & 0.765 & 9.512 & 8.805 & 0.271 & 0.130 & 0.000 & 64.5 \\
\hline 2008 & 33.315 & 24.552 & 5.278 & 2.198 & 10.104 & 8.174 & 0.541 & 0.660 & 0.000 & 64.5 \\
\hline 2009 & 35.593 & 33.315 & 9.015 & 5.278 & 10.400 & 9.774 & 0.321 & 0.630 & 0.000 & 64.5 \\
\hline 2010 & 19.112 & 35.593 & 2.381 & 9.015 & 9.841 & 9.182 & 0.131 & 0.540 & 0.000 & 64.5 \\
\hline 2011 & 33.673 & 19.112 & 3.567 & 2.381 & 10.217 & 9.876 & 0.361 & 0.560 & 0.000 & 64.5 \\
\hline 2012 & 40.214 & 33.673 & 2.551 & 3.567 & 9.923 & 9.612 & 0.561 & 0.670 & 0.000 & 64.5 \\
\hline 2013 & 20.589 & 40.214 & 1.790 & 2.551 & 9.937 & 9.660 & 0.299 & 0.310 & 0.000 & 64.5 \\
\hline 2014 & 18.879 & 20.589 & 4.182 & 1.790 & 10.243 & 9.944 & 0.789 & 0.810 & 0.000 & 64.5 \\
\hline 2005 & 2.218 & 1.546 & 0.200 & 0.172 & 9.305 & 9.455 & 0.612 & 1.102 & 0.000 & 64 \\
\hline 2006 & 5.037 & 2.218 & 0.741 & 0.200 & 9.326 & 8.412 & 0.172 & 0.592 & 0.000 & 64 \\
\hline 2007 & 2.392 & 5.037 & 0.464 & 0.741 & 8.658 & 4.913 & 0.578 & 0.428 & 0.000 & 64 \\
\hline 2008 & 3.800 & 2.392 & 0.156 & 0.464 & 8.802 & 6.068 & 0.808 & 0.868 & 0.000 & 64 \\
\hline 2009 & 3.922 & 3.800 & 2.004 & 0.156 & 9.366 & 8.075 & 0.588 & 0.728 & 0.000 & 64 \\
\hline 2010 & 4.018 & 3.922 & 1.552 & 2.004 & 9.811 & 7.760 & 0.028 & 0.358 & 0.000 & 64 \\
\hline 2011 & 3.757 & 4.018 & 0.388 & 1.552 & 10.080 & 8.483 & 0.218 & 0.588 & 0.000 & 64 \\
\hline 2012 & 3.577 & 3.757 & 5.099 & 0.388 & 10.013 & 8.884 & 0.138 & 0.428 & 0.000 & 64 \\
\hline 2013 & 2.785 & 3.577 & 3.407 & 5.099 & 9.519 & 5.869 & 0.612 & 0.592 & 0.000 & 64 \\
\hline 2014 & 7.622 & 2.785 & 0.815 & 3.407 & 9.815 & 6.377 & 0.962 & 1.112 & 0.000 & 64 \\
\hline 2005 & 4.039 & 4.569 & 12.572 & 8.153 & 10.097 & 9.613 & 0.867 & 1.357 & 0.000 & 63.5 \\
\hline 2006 & 4.316 & 4.039 & 35.125 & 12.572 & 9.889 & 9.766 & 0.417 & 0.817 & 0.693 & 63.5 \\
\hline 2007 & 4.188 & 4.316 & 18.321 & 35.125 & 10.018 & 9.638 & 0.303 & 0.233 & 0.693 & 63.5 \\
\hline 2008 & 5.629 & 4.188 & 7.473 & 18.321 & 10.184 & 9.403 & 0.703 & 0.903 & 0.693 & 63.5 \\
\hline 2009 & 6.611 & 5.629 & 10.298 & 7.473 & 9.753 & 9.359 & 0.553 & 0.783 & 0.693 & 63.5 \\
\hline 2010 & 5.211 & 6.611 & 8.003 & 10.298 & 10.097 & 9.487 & 0.023 & 0.303 & 0.000 & 63.5 \\
\hline 2011 & 5.577 & 5.211 & 26.707 & 8.003 & 10.271 & 9.628 & 0.313 & 0.533 & 0.000 & 63.5 \\
\hline 2012 & 9.312 & 5.577 & 9.687 & 26.707 & 9.800 & 9.047 & 0.413 & 0.593 & 0.000 & 63.5 \\
\hline 2013 & 4.642 & 9.312 & 15.345 & 9.687 & 10.189 & 9.812 & 0.287 & 0.317 & 0.000 & 63.5 \\
\hline 2014 & 4.757 & 4.642 & 9.596 & 15.345 & 10.349 & 9.993 & 0.737 & 0.857 & 0.000 & 63.5 \\
\hline 2005 & 9.469 & 5.031 & & - & 7.857 & & 1.116 & - & 0.000 & 63 \\
\hline
\end{tabular}




\begin{tabular}{|c|c|c|c|c|c|c|c|c|c|c|c|c|}
\hline 2006 & 10.241 & 9.469 & - & & - & & 8.632 & - & 0.656 & - & 0.000 & 63 \\
\hline 2007 & 4.709 & 10.241 & - & & - & & 9.493 & - & 0.284 & - & 0.000 & 63 \\
\hline 2008 & 15.903 & 4.709 & - & & - & & 9.373 & - & 0.854 & - & 0.000 & 63 \\
\hline 2009 & 5.810 & 15.903 & - & & - & & 8.711 & - & 0.774 & - & 0.000 & 63 \\
\hline 2010 & 4.917 & 5.810 & - & & - & & 9.344 & - & 0.106 & - & 0.000 & 63 \\
\hline 2011 & 23.995 & 4.917 & - & & - & & 9.711 & - & 0.234 & - & 0.000 & 63 \\
\hline 2012 & 5.212 & 23.995 & - & & - & & 8.703 & - & 0.364 & - & 0.000 & 63 \\
\hline 2013 & 21.006 & 5.212 & - & & - & & 6.422 & - & 0.036 & - & 0.000 & 63 \\
\hline 2014 & 47.956 & 21.006 & & 2.050 & & 3.720 & 8.717 & 8.322 & 0.596 & 0.998 & 0.000 & 63 \\
\hline 2005 & 17.660 & 13.290 & & 0.744 & & 1.127 & 13.017 & 11.143 & 1.086 & 1.411 & 0.000 & 63 \\
\hline 2006 & 17.302 & 17.660 & & 0.361 & & 0.744 & 12.956 & 10.830 & 0.478 & 0.841 & 0.000 & 63 \\
\hline 2007 & 24.281 & 17.302 & & 1.261 & & 0.361 & 13.019 & 11.091 & 0.355 & 0.189 & 0.000 & 63 \\
\hline 2008 & 25.204 & 24.281 & & 1.156 & & 1.261 & 13.022 & 10.959 & 0.932 & 1.039 & 0.000 & 63 \\
\hline 2009 & 19.090 & 25.204 & & 0.437 & & 1.156 & 12.897 & 10.563 & 0.783 & 0.889 & 1.910 & 63 \\
\hline 2010 & 21.286 & 19.090 & & 0.685 & & 0.437 & 13.136 & 11.195 & 0.115 & 0.269 & 3.258 & 63 \\
\hline 2011 & 28.047 & 21.286 & & 1.236 & & 0.685 & 12.992 & 10.774 & 0.453 & 0.479 & 3.845 & 63 \\
\hline 2012 & 30.849 & 28.047 & & 0.493 & & 1.236 & 12.931 & 10.790 & 0.633 & 0.509 & 3.845 & 63 \\
\hline 2013 & 30.130 & 30.849 & & 3.104 & & 0.493 & 12.921 & 11.320 & 0.123 & 0.211 & 3.714 & 63 \\
\hline 2014 & 34.808 & 30.130 & & 2.057 & & 3.104 & 12.898 & 12.001 & 0.438 & 0.911 & 3.534 & 63 \\
\hline 2005 & 5.287 & 6.162 & & 2.282 & & 2.232 & 10.247 & 9.691 & 0.707 & 1.242 & 0.000 & 63.5 \\
\hline 2006 & 7.476 & 5.287 & & 3.085 & & 2.282 & 11.008 & 9.529 & 0.267 & 0.762 & 0.000 & 63.5 \\
\hline 2007 & 5.289 & 7.476 & & 5.685 & & 3.085 & 10.518 & 9.408 & 0.363 & 0.268 & 0.000 & 63.5 \\
\hline 2008 & 4.701 & 5.289 & & 1.816 & & 5.685 & 10.493 & 9.133 & 0.583 & 0.778 & 0.000 & 63.5 \\
\hline 2009 & 7.244 & 4.701 & & 0.862 & & 1.816 & 10.877 & 9.706 & 0.313 & 0.638 & 0.000 & 63.5 \\
\hline 2010 & 7.937 & 7.244 & & 1.193 & & 0.862 & 11.332 & 10.420 & 0.107 & 0.308 & 0.000 & 63.5 \\
\hline 2011 & 10.227 & 7.937 & & 1.067 & & 1.193 & 11.042 & 10.140 & 0.303 & 0.528 & 0.000 & 63.5 \\
\hline 2012 & 12.238 & 10.227 & & 1.625 & & 1.067 & 10.342 & 9.717 & 0.493 & 0.628 & 0.000 & 63.5 \\
\hline 2013 & 10.304 & 12.238 & & 2.991 & & 1.625 & 10.550 & 9.830 & 0.227 & 0.292 & 0.000 & 63.5 \\
\hline 2014 & 13.417 & 10.304 & & 2.492 & & 2.991 & 10.552 & 9.523 & 0.747 & 0.852 & 0.000 & 63.5 \\
\hline 2005 & 13.024 & 10.619 & & 0.901 & & 0.061 & 10.228 & 8.090 & 1.049 & 1.270 & 0.000 & 62.5 \\
\hline 2006 & 12.760 & 13.024 & - & & - & & 9.797 & - & 0.609 & - & 0.000 & 62.5 \\
\hline 2007 & 24.226 & 12.760 & - & & - & & 9.900 & - & 0.361 & - & 0.000 & 62.5 \\
\hline 2008 & 18.266 & 24.226 & & 1.064 & & 0.140 & 10.097 & 6.572 & 0.881 & 1.090 & 0.000 & 62.5 \\
\hline 2009 & 12.434 & 18.266 & & 0.244 & & 1.064 & 10.580 & 8.207 & 0.721 & 0.880 & 0.000 & 62.5 \\
\hline 2010 & 22.884 & 12.434 & & 0.445 & & 0.244 & 10.988 & 9.310 & 0.149 & 0.060 & 0.000 & 62.5 \\
\hline 2011 & 29.165 & 22.884 & & 0.283 & & 0.445 & 10.662 & 8.593 & 0.171 & 0.390 & 0.000 & 62.5 \\
\hline 2012 & 24.702 & 29.165 & - & & - & & 10.393 & - & 0.301 & - & 0.000 & 62.5 \\
\hline 2013 & 25.312 & 24.702 & - & & - & & 10.320 & - & 0.069 & - & 0.000 & 62.5 \\
\hline 2014 & 32.949 & 25.312 & & 1.665 & & 0.949 & 10.135 & 7.653 & 0.559 & 0.960 & 0.000 & 62.5 \\
\hline
\end{tabular}




\begin{tabular}{|c|c|c|c|c|c|c|c|c|c|c|}
\hline 2005 & 30.679 & 26.742 & 1.100 & 1.163 & 12.202 & 10.412 & 0.937 & 1.336 & 0.000 & 62.5 \\
\hline 2006 & 27.538 & 30.679 & 3.046 & 1.100 & 12.096 & 9.675 & 0.437 & 0.716 & 0.000 & 62.5 \\
\hline 2007 & 28.628 & 27.538 & 0.392 & 3.046 & 12.402 & 9.205 & 0.283 & 0.284 & 1.322 & 62.5 \\
\hline 2008 & 29.474 & 28.628 & 0.928 & 0.392 & 12.196 & 9.371 & 0.803 & 1.014 & 1.322 & 62.5 \\
\hline 2009 & 21.280 & 29.474 & 0.624 & 0.928 & 12.272 & 10.322 & 0.543 & 0.804 & 1.322 & 62.5 \\
\hline 2010 & 20.108 & 21.280 & 0.278 & 0.624 & 12.744 & 11.184 & 0.097 & 0.214 & 1.322 & 62.5 \\
\hline 2011 & 28.190 & 20.108 & 0.278 & 0.278 & 12.839 & 10.977 & 0.163 & 0.404 & 3.350 & 62.5 \\
\hline 2012 & 25.422 & 28.190 & 0.345 & 0.278 & 12.792 & 10.586 & 0.373 & 0.424 & 3.350 & 62.5 \\
\hline 2013 & 24.965 & 25.422 & 1.719 & 0.345 & 12.716 & 11.257 & 0.067 & 0.216 & 3.350 & 62.5 \\
\hline 2014 & 35.989 & 24.965 & 2.269 & 1.719 & 12.867 & 11.802 & 0.627 & 0.876 & 3.376 & 62.5 \\
\hline 2005 & 26.422 & 21.060 & 1.532 & 2.736 & 11.482 & 10.932 & 0.979 & $1.448^{-}$ & 0.000 & 62 \\
\hline 2006 & 26.139 & 26.422 & 1.749 & 1.532 & 10.746 & 9.393 & 0.369 & 0.668 & 0.000 & 62 \\
\hline 2007 & 14.793 & 26.139 & 0.462 & 1.749 & 11.365 & 10.703 & 0.321 & 0.332 & 0.000 & 62 \\
\hline 2008 & 27.428 & 14.793 & 2.095 & 0.462 & 11.402 & 10.508 & 0.761 & 0.962 & 0.000 & 62 \\
\hline 2009 & 21.887 & 27.428 & 2.416 & 2.095 & 11.102 & 10.443 & 0.411 & 0.682 & 0.000 & 62 \\
\hline 2010 & 35.969 & 21.887 & 3.861 & 2.416 & 11.123 & 10.812 & 0.219 & 0.082 & 2.398 & 62 \\
\hline 2011 & 33.147 & 35.969 & 2.928 & 3.861 & 11.239 & 11.019 & 0.101 & 0.372 & 2.848 & 62 \\
\hline 2012 & 30.720 & 33.147 & 1.894 & 2.928 & 11.182 & 10.629 & 0.421 & 0.482 & 2.848 & 62 \\
\hline 2013 & 23.981 & 30.720 & 2.953 & 1.894 & 11.207 & 10.843 & 0.061 & 0.068 & 2.848 & 62 \\
\hline 2014 & 31.450 & 23.981 & 7.854 & 2.953 & 11.262 & 11.061 & 0.509 & 0.728 & 1.981 & 62 \\
\hline 2005 & 19.331 & 16.194 & 7.397 & 9.213 & 12.189 & 12.069 & 0.904 & 1.393 & 3.045 & 61.5 \\
\hline 2006 & 21.389 & 19.331 & 9.778 & 7.397 & 12.089 & 11.861 & 0.294 & 0.553 & 4.193 & 61.5 \\
\hline 2007 & 22.013 & 21.389 & 10.361 & 9.778 & 11.942 & 11.658 & 0.366 & 0.437 & 5.053 & 61.5 \\
\hline 2008 & 15.251 & 22.013 & 7.493 & 10.361 & 11.812 & 11.359 & 0.676 & 0.887 & 5.672 & 61.5 \\
\hline 2009 & 8.426 & 15.251 & 8.169 & 7.493 & 11.826 & 11.426 & 0.296 & 0.517 & 6.319 & 61.5 \\
\hline 2010 & 16.597 & 8.426 & 12.659 & 8.169 & 11.989 & 11.764 & $0.404^{-}$ & $0.153^{-}$ & 6.843 & 61.5 \\
\hline 2011 & 17.775 & 16.597 & 12.075 & 12.659 & 11.732 & 11.605 & 0.056 & 0.337 & 7.329 & 61.5 \\
\hline 2012 & 22.244 & 17.775 & 10.528 & 12.075 & 11.844 & 11.601 & 0.456 & 0.517 & 7.577 & 61.5 \\
\hline 2013 & 20.125 & 22.244 & 9.593 & 10.528 & 11.675 & 11.471 & 0.156 & 0.027 & 7.780 & 61.5 \\
\hline 2014 & 22.467 & 20.125 & 17.395 & 9.593 & 11.621 & 11.500 & 0.404 & 0.623 & 7.992 & 61.5 \\
\hline 2005 & 25.192 & 21.773 & 4.023 & 3.465 & 12.209 & 11.981 & 0.836 & 1.365 & 1.558 & 61 \\
\hline 2006 & 26.993 & 25.192 & 5.420 & 4.023 & 12.095 & 11.727 & 0.166 & 0.405 & 3.618 & 61 \\
\hline 2007 & 21.742 & 26.993 & 3.484 & 5.420 & 12.298 & 11.899 & 0.384 & 0.455 & 5.328 & 61 \\
\hline 2008 & 15.845 & 21.742 & 1.769 & 3.484 & 12.191 & 11.791 & 0.714 & 0.955 & 6.110 & 61 \\
\hline 2009 & 8.577 & 15.845 & 1.244 & 1.769 & 12.203 & 11.684 & 0.294 & 0.505 & 6.609 & 61 \\
\hline 2010 & 14.990 & 8.577 & 2.111 & 1.244 & 12.117 & 11.577 & 0.426 & $0.175^{-}$ & 7.076 & 61 \\
\hline 2011 & 18.179 & 14.990 & 2.418 & 2.111 & 11.988 & 11.613 & 0.006 & 0.285 & 7.449 & 61 \\
\hline 2012 & 21.608 & 18.179 & 1.097 & 2.418 & 11.941 & 11.355 & 0.384 & 0.465 & 7.697 & 61 \\
\hline 2013 & 18.089 & 21.608 & 2.053 & 1.097 & 11.718 & 11.059 & 0.104 & 0.045 & 7.924 & 61 \\
\hline
\end{tabular}




\begin{tabular}{|c|c|c|c|c|c|c|c|c|c|c|}
\hline 2014 & 22.860 & 18.089 & 1.694 & 2.053 & 11.655 & 10.864 & 0.446 & 0.675 & 7.948 & 61 \\
\hline 2005 & 27.544 & 21.368 & 36.246 & 31.384 & 12.683 & 12.762 & 1.128 & 1.643 & 1.658 & 60.5 \\
\hline 2006 & 24.893 & 27.544 & 23.986 & 36.246 & 12.751 & 12.719 & 0.338 & 0.583 & 4.047 & 60.5 \\
\hline 2007 & 22.996 & 24.893 & 23.122 & 23.986 & 12.759 & 12.779 & 0.262 & 0.267 & 4.970 & 60.5 \\
\hline 2008 & 23.790 & 22.996 & 22.010 & 23.122 & 12.761 & 12.727 & 0.782 & 1.047 & 5.610 & 60.5 \\
\hline 2009 & 12.718 & 23.790 & 19.285 & 22.010 & 12.634 & 12.550 & 0.402 & 0.627 & 6.251 & 60.5 \\
\hline 2010 & 20.380 & 12.718 & 17.424 & 19.285 & 12.815 & 12.797 & 0.278 & 0.067 & 6.641 & 60.5 \\
\hline 2011 & 22.625 & 20.380 & 31.130 & 17.424 & 12.818 & 12.785 & 0.022 & 0.327 & 6.996 & 60.5 \\
\hline 2012 & 24.559 & 22.625 & 25.093 & 31.130 & 12.742 & 12.752 & 0.402 & 0.487 & 7.115 & 60.5 \\
\hline 2013 & 28.853 & 24.559 & 19.820 & 25.093 & 12.717 & 12.696 & 0.172 & 0.023 & 7.084 & 60.5 \\
\hline 2014 & 52.489 & 28.853 & 26.074 & 19.820 & 12.584 & 12.600 & 0.298 & 0.573 & 6.989 & 60.5 \\
\hline 2005 & 36.887 & 34.006 & 28.538 & 37.619 & 11.567 & 11.400 & 1.336 & 1.604 & 0.000 & 60 \\
\hline 2006 & 41.952 & 36.887 & 48.568 & 28.538 & 11.478 & 11.296 & 0.636 & 0.754 & 0.000 & 60 \\
\hline 2007 & 44.363 & 41.952 & 42.917 & 48.568 & 11.333 & 11.051 & 0.164 & 0.096 & 0.000 & 60 \\
\hline 2008 & 47.749 & 44.363 & 28.654 & 42.917 & 11.300 & 11.035 & 0.894 & 1.016 & 0.000 & 60 \\
\hline 2009 & 47.203 & 47.749 & 33.814 & 28.654 & 11.251 & 10.920 & 0.724 & 0.856 & 0.000 & 60 \\
\hline 2010 & 71.038 & 47.203 & 45.424 & 33.814 & 11.093 & 10.694 & 0.166 & 0.186 & 0.000 & 60 \\
\hline 2011 & 78.915 & 71.038 & 53.931 & 45.424 & 10.982 & 10.715 & 0.014 & 0.366 & 0.000 & 60 \\
\hline 2012 & 92.114 & 78.915 & 37.162 & 53.931 & 11.310 & 10.967 & 0.234 & 0.326 & 0.000 & 60 \\
\hline 2013 & 62.831 & 92.114 & 26.338 & 37.162 & 11.226 & 10.815 & 0.284 & 0.026 & 0.000 & 60 \\
\hline 2014 & 71.234 & 62.831 & 34.552 & 26.338 & 11.386 & 10.970 & 0.176 & 0.514 & 0.000 & 60 \\
\hline 2005 & 27.161 & 23.152 & 12.889 & 21.376 & 12.149 & 11.126 & $1.319^{-}$ & 1.646 & 0.000 & 60 \\
\hline 2006 & 38.139 & 27.161 & 22.186 & 12.889 & 11.975 & 10.550 & 0.489 & $0.636^{-}$ & 0.000 & 60 \\
\hline 2007 & 35.351 & 38.139 & 13.741 & 22.186 & 11.914 & 10.878 & 0.171 & 0.134 & 0.000 & 60 \\
\hline 2008 & 32.390 & 35.351 & 8.258 & 13.741 & 11.926 & 10.783 & 0.901 & 1.104 & 0.000 & 60 \\
\hline 2009 & 22.876 & 32.390 & 8.719 & 8.258 & 11.794 & 10.630 & 0.601 & 0.804 & 0.000 & 60 \\
\hline 2010 & 32.368 & 22.876 & 17.726 & 8.719 & 11.593 & 10.372 & 0.149 & 0.224 & 2.442 & 60 \\
\hline 2011 & 42.197 & 32.368 & 7.643 & 17.726 & 11.404 & 9.481 & 0.001 & 0.314 & 3.239 & 60 \\
\hline 2012 & 57.617 & 42.197 & 8.809 & 7.643 & 11.759 & 10.680 & 0.301 & 0.334 & 3.239 & 60 \\
\hline 2013 & 50.976 & 57.617 & 9.699 & 8.809 & 11.447 & 9.936 & 0.231 & 0.046 & 3.239 & 60 \\
\hline 2014 & 56.280 & 50.976 & 18.821 & 9.699 & 11.470 & 10.094 & 0.249 & 0.586 & 3.114 & 60 \\
\hline 2005 & 28.509 & 19.050 & 23.256 & 27.685 & 12.161 & 12.258 & 1.237 & 1.672 & 3.229 & 60 \\
\hline 2006 & 35.825 & 28.509 & 25.492 & 23.256 & 12.119 & 12.136 & 0.437 & 0.612 & 3.555 & 60 \\
\hline 2007 & 30.000 & 35.825 & 21.569 & 25.492 & 11.838 & 11.826 & 0.153 & 0.148 & 4.252 & 60 \\
\hline 2008 & 24.264 & 30.000 & 24.425 & 21.569 & 11.668 & 11.696 & 0.813 & 1.068 & 4.670 & 60 \\
\hline 2009 & 13.346 & 24.264 & 11.820 & 24.425 & 11.396 & 11.334 & 0.483 & 0.708 & 5.215 & 60 \\
\hline 2010 & 23.678 & 13.346 & 11.136 & 11.820 & 11.387 & 11.415 & 0.197 & 0.158 & 5.745 & 60 \\
\hline 2011 & 29.954 & 23.678 & 27.765 & 11.136 & 11.306 & 11.489 & 0.047 & 0.268 & 6.187 & 60 \\
\hline 2012 & 37.946 & 29.954 & 24.535 & 27.765 & 11.588 & 11.538 & 0.353 & 0.388 & 6.305 & 60 \\
\hline
\end{tabular}




\begin{tabular}{|c|c|c|c|c|c|c|c|c|c|c|}
\hline 2013 & 53.535 & 37.946 & 19.975 & 24.535 & 11.464 & 11.494 & 0.253 & 0.018 & 6.479 & 60 \\
\hline 2014 & 55.925 & 53.535 & 24.913 & 19.975 & 10.843 & 10.795 & 0.137 & 0.472 & 6.757 & 60 \\
\hline 2005 & 11.848 & 8.297 & 31.640 & 36.156 & 12.311 & 12.512 & 1.102 & 1.607 & 3.442 & 60 \\
\hline 2006 & 10.031 & 11.848 & 36.258 & 31.640 & 12.275 & 12.387 & 0.322 & 0.557 & 4.369 & 60 \\
\hline 2007 & 9.828 & 10.031 & 37.396 & 36.258 & 12.403 & 12.516 & 0.138 & 0.173 & 5.372 & 60 \\
\hline 2008 & 10.412 & 9.828 & 36.166 & 37.396 & 12.404 & 12.473 & 0.768 & 1.083 & 5.878 & 60 \\
\hline 2009 & 6.884 & 10.412 & 27.348 & 36.166 & 12.186 & 12.232 & 0.398 & 0.673 & 6.497 & 60 \\
\hline 2010 & 8.520 & 6.884 & 24.601 & 27.348 & 12.271 & 12.351 & 0.162 & 0.233 & 6.999 & 60 \\
\hline 2011 & 10.239 & 8.520 & 34.714 & 24.601 & 12.268 & 12.387 & 0.002 & 0.263 & 7.195 & 60 \\
\hline 2012 & 10.225 & 10.239 & 33.586 & 34.714 & 12.217 & 12.361 & 0.418 & 0.423 & 7.339 & 60 \\
\hline 2013 & 7.128 & 10.225 & 26.882 & 33.586 & 12.201 & 12.255 & 0.208 & 0.027 & 7.473 & 60 \\
\hline 2014 & 8.325 & 7.128 & 25.413 & 26.882 & 12.037 & 12.161 & 0.342 & 0.657 & 7.405 & 60 \\
\hline 2005 & 7.177 & 6.727 & 26.793 & 26.975 & 11.417 & 11.507 & 0.753 & 1.382 & 3.080 & 60 \\
\hline 2006 & 4.347 & 7.177 & 24.959 & 26.793 & 11.036 & 11.257 & 0.053 & 0.332 & 4.245 & 60 \\
\hline 2007 & 7.078 & 4.347 & 23.887 & 24.959 & 11.221 & 11.344 & 0.227 & 0.338 & 5.116 & 60 \\
\hline 2008 & 9.776 & 7.078 & 20.577 & 23.887 & 11.028 & 11.093 & 0.647 & 1.088 & 5.784 & 60 \\
\hline 2009 & 6.566 & 9.776 & 14.144 & 20.577 & 10.489 & 10.596 & 0.197 & 0.598 & 6.292 & 60 \\
\hline 2010 & 4.733 & 6.566 & 15.956 & 14.144 & 11.071 & 11.211 & 0.313 & 0.108 & 6.573 & 60 \\
\hline 2011 & 7.359 & 4.733 & 13.619 & 15.956 & 11.104 & 11.222 & 0.037 & 0.188 & 6.887 & 60 \\
\hline 2012 & 7.411 & 7.359 & 20.640 & 13.619 & 11.338 & 11.493 & 0.417 & 0.338 & 7.151 & 60 \\
\hline 2013 & 4.533 & 7.411 & 13.996 & 20.640 & 10.402 & 10.608 & 0.137 & 0.132 & 7.409 & 60 \\
\hline 2014 & 4.534 & 4.533 & 25.096 & 13.996 & 10.557 & 10.864 & 0.543 & 0.812 & 7.567 & 60 \\
\hline 2005 & 5.872 & 5.102 & 28.511 & 22.634 & 11.810 & 11.948 & 0.806 & 1.461 & 0.000 & 60 \\
\hline 2006 & 6.008 & 5.872 & 34.662 & 28.511 & 11.341 & 11.560 & 0.136 & 0.431 & 0.000 & 60 \\
\hline 2007 & 5.796 & 6.008 & 33.234 & 34.662 & 11.515 & 11.676 & 0.144 & 0.259 & 0.000 & 60 \\
\hline 2008 & 8.199 & 5.796 & 29.169 & 33.234 & 11.473 & 11.585 & 0.564 & 0.999 & 1.099 & 60 \\
\hline 2009 & 7.966 & 8.199 & 35.120 & 29.169 & 11.260 & 11.400 & 0.154 & 0.529 & 3.209 & 60 \\
\hline 2010 & 10.640 & 7.966 & 38.051 & 35.120 & 11.359 & 11.461 & 0.276 & 0.139 & 4.500 & 60 \\
\hline 2011 & 12.612 & 10.640 & 41.313 & 38.051 & 11.428 & 11.569 & 0.084 & 0.219 & 5.115 & 60 \\
\hline 2012 & 18.333 & 12.612 & 42.737 & 41.313 & 11.322 & 11.523 & 0.514 & 0.449 & 5.559 & 60 \\
\hline 2013 & 6.818 & 18.333 & 28.035 & 42.737 & 10.929 & 11.130 & 0.164 & 0.051 & 5.883 & 60 \\
\hline 2014 & 14.824 & 6.818 & 39.047 & 28.035 & 10.897 & 11.172 & 0.406 & 0.651 & 6.111 & 60 \\
\hline 2005 & 11.224 & 9.751 & 26.005 & 19.505 & 11.138 & 11.240 & 0.667 & 1.267 & 5.724 & 60 \\
\hline 2006 & 10.895 & 11.224 & 28.503 & 26.005 & 10.892 & 10.960 & 0.057 & 0.317 & 6.110 & 60 \\
\hline 2007 & 11.407 & 10.895 & 23.774 & 28.503 & 11.024 & 11.367 & 0.223 & 0.353 & 6.400 & 60 \\
\hline 2008 & 10.312 & 11.407 & 19.223 & 23.774 & 10.927 & 11.140 & 0.583 & 1.003 & 6.477 & 60 \\
\hline 2009 & 8.383 & 10.312 & 20.822 & 19.223 & 11.057 & 11.107 & 0.083 & 0.443 & 6.643 & 60 \\
\hline 2010 & 9.374 & 8.383 & 29.195 & 20.822 & 11.027 & 11.203 & 0.447 & 0.057 & 6.791 & 60 \\
\hline
\end{tabular}




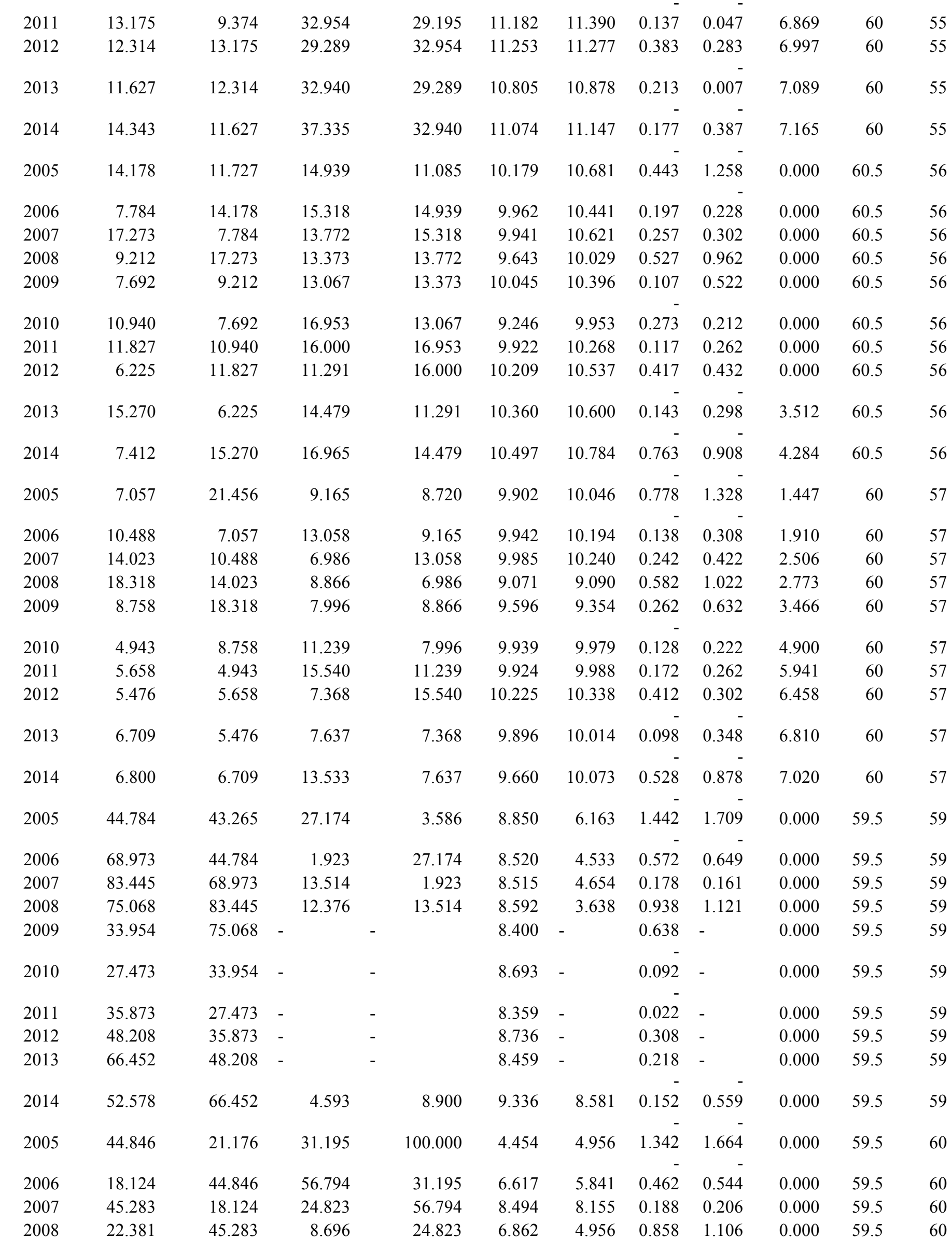




\begin{tabular}{|c|c|c|c|c|c|c|c|c|c|c|c|}
\hline 2009 & 7.481 & 22.381 & 83.333 & & 8.696 & 5.352 & 5.088 & 0.518 & 0.746 & 0.000 & 59.5 \\
\hline 2010 & 35.308 & 7.481 & - & - & & 5.996 & - & 0.122 & - & 0.000 & 59.5 \\
\hline 2011 & 2.302 & 35.308 & - & - & & 6.087 & - & 0.032 & - & 0.000 & 59.5 \\
\hline 2012 & 27.322 & 2.302 & - & - & & 8.684 & - & 0.298 & - & 0.000 & 59.5 \\
\hline 2013 & 53.365 & 27.322 & - & - & & 5.905 & - & 0.218 & - & 0.000 & 59.5 \\
\hline 2014 & 16.631 & 53.365 & - & - & & 6.461 & - & $0.122^{-}$ & - & 0.000 & 59.5 \\
\hline 2005 & 14.853 & 14.779 & 24.836 & & 32.625 & 11.389 & 11.382 & 1.074 & $1.490^{-}$ & 2.351 & 59.5 \\
\hline 2006 & 15.007 & 14.853 & 23.202 & & 24.836 & 11.197 & 11.162 & $0.294^{-}$ & $0.420^{-}$ & 3.332 & 59.5 \\
\hline 2007 & 14.027 & 15.007 & 19.054 & & 23.202 & 11.365 & 11.354 & 0.196 & 0.270 & 4.379 & 59.5 \\
\hline 2008 & 15.499 & 14.027 & 21.654 & & 19.054 & 11.264 & 11.211 & 0.776 & 1.110 & 5.014 & 59.5 \\
\hline 2009 & 17.077 & 15.499 & 22.838 & & 21.654 & 11.136 & 11.064 & 0.416 & 0.690 & 5.528 & 59.5 \\
\hline 2010 & 19.261 & 17.077 & 28.096 & & 22.838 & 10.904 & 10.787 & $0.134^{-}$ & 0.230 & 6.143 & 59.5 \\
\hline 2011 & 21.627 & 19.261 & 35.104 & & 28.096 & 10.805 & 10.773 & 0.024 & 0.200 & 6.405 & 59.5 \\
\hline 2012 & 24.531 & 21.627 & 29.201 & & 35.104 & 10.853 & 10.861 & 0.316 & 0.260 & 6.529 & 59.5 \\
\hline 2013 & 25.823 & 24.531 & 26.080 & & 29.201 & 10.864 & 10.796 & 0.126 & 0.160 & 6.567 & 59.5 \\
\hline 2014 & 20.496 & 25.823 & 31.495 & & 26.080 & 10.708 & 10.655 & $0.304^{-}$ & $0.690^{-}$ & 6.277 & 59.5 \\
\hline 2005 & 9.119 & 11.495 & 30.273 & & 35.935 & 11.595 & 11.728 & 0.980 & 1.476 & 6.268 & 59.5 \\
\hline 2006 & 10.329 & 9.119 & 27.102 & & 30.273 & 11.472 & 11.552 & $0.170^{-}$ & $0.36 \overline{6}$ & 6.495 & 59.5 \\
\hline 2007 & 11.513 & 10.329 & 23.229 & & 27.102 & 11.511 & 11.651 & 0.270 & 0.374 & 6.600 & 59.5 \\
\hline 2008 & 9.324 & 11.513 & 21.458 & & 23.229 & 11.584 & 11.717 & 0.760 & 1.174 & 6.604 & 59.5 \\
\hline 2009 & 11.760 & 9.324 & 17.906 & & 21.458 & 11.441 & 11.416 & 0.330 & 0.694 & 6.659 & 59.5 \\
\hline 2010 & 14.556 & 11.760 & 21.406 & & 17.906 & 11.419 & 11.446 & 0.200 & 0.204 & 6.628 & 59.5 \\
\hline 2011 & 16.436 & 14.556 & 21.920 & & 21.406 & 11.568 & 11.633 & 0.010 & 0.144 & 6.536 & 59.5 \\
\hline 2012 & 13.909 & 16.436 & 22.455 & & 21.920 & 11.726 & 11.757 & 0.320 & 0.204 & 6.368 & 59.5 \\
\hline 2013 & 13.743 & 13.909 & 22.191 & & 22.455 & 11.387 & 11.407 & 0.090 & $0.186^{-}$ & 6.078 & 59.5 \\
\hline 2014 & 13.878 & 13.743 & 25.656 & & 22.191 & 11.209 & 11.290 & $0.410^{-}$ & 0.766 & 5.899 & 59.5 \\
\hline
\end{tabular}


684 Supplementary Table 2. Average annual growth rate of log-transformed perch and 685 pikeperch CPUE values during 2005-2014 and maximum breeding cormorant 686 numbers during 2003-2012 in ICES grids. Significant coefficients are bolded.

\begin{tabular}{|c|c|c|c|}
\hline ICES & Perch & Pikeperch & Cormorant max \\
\hline 2 & $0.111 \pm 0.020$ & $0.022 \pm 0.047$ & 0 \\
\hline 6 & $0.054 \pm 0.026$ & $-0.004 \pm 0.044$ & 240 \\
\hline 7 & $0.096 \pm 0.024$ & $0.123 \pm 0.040$ & 47 \\
\hline 11 & $0.043 \pm 0.041$ & $0.080 \pm 0.070$ & 4 \\
\hline 12 & $-0.062 \pm 0.032$ & - & 0 \\
\hline 15 & $0.054 \pm 0.037$ & $0.185 \pm 0.114$ & 0 \\
\hline 19 & $0.035 \pm 0.027$ & $-0.048 \pm 0.058$ & 4 \\
\hline 22 & $0.129 \pm 0.080$ & - & 0 \\
\hline 23 & $0.070 \pm 0.015$ & $0.122 \pm 0.068$ & 83 \\
\hline 24 & $0.105 \pm 0.022$ & $-0.042 \pm 0.065$ & 0 \\
\hline 27 & $0.093 \pm 0.026$ & - & 0 \\
\hline 28 & $-0.000 \pm 0.020$ & $-0.016 \pm 0.103$ & 110 \\
\hline 32 & $0.034 \pm 0.027$ & $0.163 \pm 0.062$ & 40 \\
\hline 37 & $0.013 \pm 0.034$ & $0.058 \pm 0.023$ & 3981 \\
\hline 42 & $-0.017 \pm 0.038$ & $-0.114 \pm 0.043$ & 3426 \\
\hline 47 & $0.045 \pm 0.038$ & $-0.018 \pm 0.025$ & 1654 \\
\hline 49 & $0.087 \pm 0.019$ & $-0.007 \pm 0.029$ & 0 \\
\hline 50 & $0.074 \pm 0.025$ & $-0.025 \pm 0.044$ & 56 \\
\hline 51 & $0.068 \pm 0.042$ & $-0.001 \pm 0.038$ & 1389 \\
\hline 52 & $-0.032 \pm 0.017$ & $-0.029 \pm 0.016$ & 2179 \\
\hline 53 & $-0.029 \pm 0.031$ & $-0.039 \pm 0.028$ & 2437 \\
\hline
\end{tabular}




\begin{tabular}{lrrr}
54 & $\mathbf{0 . 1 0 0} \pm \mathbf{0 . 0 3 3}$ & $0.023 \pm 0.016$ & 629 \\
55 & $0.024 \pm 0.016$ & $\mathbf{0 . 0 4 4} \pm \mathbf{0 . 0 1 9}$ & 1519 \\
56 & $-0.031 \pm 0.039$ & $0.003 \pm 0.015$ & 156 \\
57 & $-0.074 \pm 0.043$ & $0.012 \pm 0.033$ & 1264 \\
59 & $-0.024 \pm 0.043$ & - & 0 \\
60 & $-0.056 \pm 0.111$ & - & 0 \\
61 & $\mathbf{0 . 0 6 4} \pm \mathbf{0 . 0 1 2}$ & $\mathbf{0 . 0 4 1} \pm \mathbf{0 . 0 1 6}$ & 925 \\
62 & $\mathbf{0 . 0 5 2} \pm \mathbf{0 . 0 1 4}$ & $-0.017 \pm 0.016$ & 879 \\
\hline
\end{tabular}

687

688

689 